\title{
Phytoplankton distribution and nitrogen dynamics in the southwest indian subtropical gyre and Southern Ocean waters
}

\author{
S. J. Thomalla ${ }^{1,2}$, H. N. Waldron ${ }^{1}$, M. I. Lucas ${ }^{3}$, J. F. Read ${ }^{4}$, I. J. Ansorge ${ }^{1}$, and E. Pakhomov ${ }^{5,6}$ \\ ${ }^{1}$ Department of Oceanography, University of Cape Town, Private Bag, Rondebosch, Cape Town 7701, South Africa \\ ${ }^{2}$ Ocean Systems and Climate Group, CSIR, P.O. Box 320 Stellenbosch, 7599, South Africa \\ ${ }^{3}$ Department of Zoology, University of Cape Town, Private Bag, Rondebosch, Cape Town 7701, South Africa \\ ${ }^{4}$ National Oceanographic Centre (NOC), Southampton, SO143ZH, UK \\ ${ }^{5}$ Department of Earth and Ocean Sciences, 6339 Stores Road, Univ. of British Columbia, Vancouver, BC, V6T 1Z4, Canada \\ ${ }^{6}$ Department of Zoology, University of Fort Hare, Private Bag X1314, Alice 5700, South Africa
}

Received: 18 June 2010 - Published in Ocean Sci. Discuss.: 23 July 2010

Revised: 18 January 2011 - Accepted: 23 January 2011 - Published: 8 February 2011

\begin{abstract}
During the 1999 Marion Island Oceanographic Survey (MIOS 4) in late austral summer, a northbound and reciprocal southbound transect were taken along the Southwest Indian and Madagascar Ridge, between the Prince Edward Islands and $31^{\circ} \mathrm{S}$. The sections crossed a number of major fronts and smaller mesoscale features and covered a wide productivity spectrum from subtropical to subantarctic waters. Associated with the physical survey were measurements of size fractionated chlorophyll, nutrients and nitrogen $\left(\mathrm{NO}_{3}, \mathrm{NH}_{4}\right.$ and urea) uptake rates. Subtropical waters were characterised by low chlorophyll concentrations ( $\max =0.27 .3 \mathrm{mg} \mathrm{m}^{-3}$ ) dominated by picophytoplankton cells $(>81 \%)$ and very low f-ratios $(<0.1)$, indicative of productivity based almost entirely on recycled ammonium and urea. Micro-phytoplankton growth was limited by the availability of $\mathrm{NO}_{3}\left(<0.5 \mathrm{mmol} \mathrm{m}^{-3}\right)$ and $\mathrm{Si}(\mathrm{OH})_{4}\left(<1.5 \mathrm{mmol} \mathrm{m}^{-3}\right)$ through strong vertical stratification preventing the upward flux of nutrients into the euphotic zone. Biomass accumulation of small cells was likely controlled by micro-zooplankton grazing. In subantarctic waters, total chlorophyll concentrations increased $\left(\max =0.74 \mathrm{mg} \mathrm{m}^{-3}\right)$ relative to the subtropical waters and larger cells became more prevalent, however smaller phytoplankton cells and low f-ratios $(<0.14)$ still dominated, despite sufficient $\mathrm{NO}_{3}$ availability. The results from this study favour $\mathrm{Si}(\mathrm{OH})_{4}$ limitation, light-limited deep mixing and likely Fe deficiency as the dominant mechanisms controlling significant new production by micro-phytoplankton.
\end{abstract}

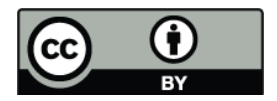

Correspondence to: S. J. Thomalla (sandy.thomalla@gmail.com)
The percentage of micro-phytoplankton cells and rates of new production did however increase at oceanic frontal regions (58.6\% and $11.22 \%$, respectively), and in the region of the Prince Edward archipelago (61.4\% and $14.16 \%$, respectively). Here, water column stabilization and local Feenrichment are thought to stimulate phytoplankton growth rates. Open ocean regions such as these provide important areas for local but significant particulate organic carbon export and biological $\mathrm{CO}_{2}$ draw-down in an overall high nutrient low chlorophyll Southern Ocean.

\section{Introduction}

The "biological carbon pump" (Volk and Hoffert, 1985; Longhurst, 1991; Falkowski and Raven, 1997) provides a link between the atmospheric and oceanic carbon cycles, primarily through phytoplankton photosynthesis and carbon export processes. The biological pump plays an important role in ameliorating current increases in atmospheric $\mathrm{CO}_{2}$ by removing an estimated 11 to $16 \mathrm{Pg}\left(1 \mathrm{Pg}=10^{15} \mathrm{~g}\right.$ of carbon) from surface waters of the world's oceans each year (Falkowski et al., 2000). The rate at which inorganic carbon is fixed into particulate and dissolved organic carbon (POC, DOC) that sinks, or is otherwise transported through the water column to below the seasonal thermocline, sets the strength of the biological carbon pump. Thus, factors that regulate phytoplankton growth (light, nutrients), particle formation and rates of sinking (aggregation, ballasting, senescence, grazing) and remineralisation (bacterial activity, chemical dissolution) all modify POC and DOC fluxes and therefore the strength of the biological carbon pump.

Published by Copernicus Publications on behalf of the European Geosciences Union. 
The sub-Antarctic region of the Southern Ocean is one of the largest oceanic sinks for atmospheric $\mathrm{CO}_{2}$ (Metzl et al., 1999). The SW Indian Ocean region is infrequently sampled (Lucas et al., 2007) and for both regions, measurements of carbon export are relatively few. In this paper, indirect estimates of carbon export are made using ${ }^{15} \mathrm{~N}$ stable isotopes that differentiate between "new" (export) and "regenerated" (recycled) production (Dugdale and Goering, 1967; Eppley and Peterson, 1979; Bury et al., 1995; Waldron et al., 1995). Partitioning between new and regenerated nitrogen uptake is quantified by the f-ratio, a measure of that fraction of "new" primary production that is available for export to the deep ocean or to higher trophic levels, relative to "regenerated" production which supports planktonic community maintenance requirements (Tremblay et al., 1997). f-ratio calculations rely on assumptions of steady state, no storage of nitrogen $(\mathrm{N})$ in surface waters (Eppley and Peterson, 1979; Eppley, 1989; Knauer et al., 1990) and minimal euphotic layer nitrification (Fernandez and Raimbault, 2007; Yool et al., 2007). Although rates of euphotic nitrification are significant in the oligotrohpic, hindering the use of the f-ratio for diagnosing export production, this is not the case in the nutrient-rich polar oceans (Dore and Karl, 1996; Raimbault et al., 1999; Diaz and Raimbault, 2000; Rees et al., 2002; Fernandez and Raimbault, 2007; Yool et al., 2007). Further problems arise when expressing particulate organic nitrogen (PON) export in carbon terms as phytoplankton growth frequently follows non-Redfield ratios because of disturbances to cellular Redfield elemental stoichiometry by light and/or available $\mathrm{Si}$ and $\mathrm{Fe}$ (Geider and La Roche, 2002; Timmermans et al., 2004; Hoffmann et al., 2006; Moore et al., 2007b). Thus use of the f-ratio to estimate export production from the euphotic layer must be considered with circumspection, although in high nutrient low chlorophyll (HNLC) environments, the f-ratio can be an instructive diagnostic tool for evaluating the potential for carbon export.

In this paper, we report on new and regenerated production measurements made along a transect from $31^{\circ} \mathrm{S}$ (just $\mathrm{SW}$ of Madagascar) to the Prince Edward Islands $\left(45^{\circ} \mathrm{S}\right)$ following the Madagascar and SW Indian ridge (Fig. 1). The transect progresses across regions of complex frontal boundaries and variable biogeochemistry, phytoplankton distribution and productivity associated with the transition from oligotrophic and nutrient impoverished subtropical gyres to macro-nutrient replete but iron deficient subantarctic domains (Barange et al., 1998; Bathmann et al., 2000; Read et al., 2000; Pollard et al., 2007). The major frontal systems crossed south of Africa include the Agulhas Front (AF), the Subtropical Front (STF) the sub-Antarctic Front (SAF) and the Antarctic Polar Front (APF) (see Belkin and Gordon, 1996; Pollard and Read, 2001; Pollard et al., 2002). Collectively they create one of the most energetic and important hydrographic regions of the world oceans (Lutjeharms and Ansorge, 2001) and one that is likely to have strong iron (Fe) gradients (Planquette et al., 2007). This environment there-

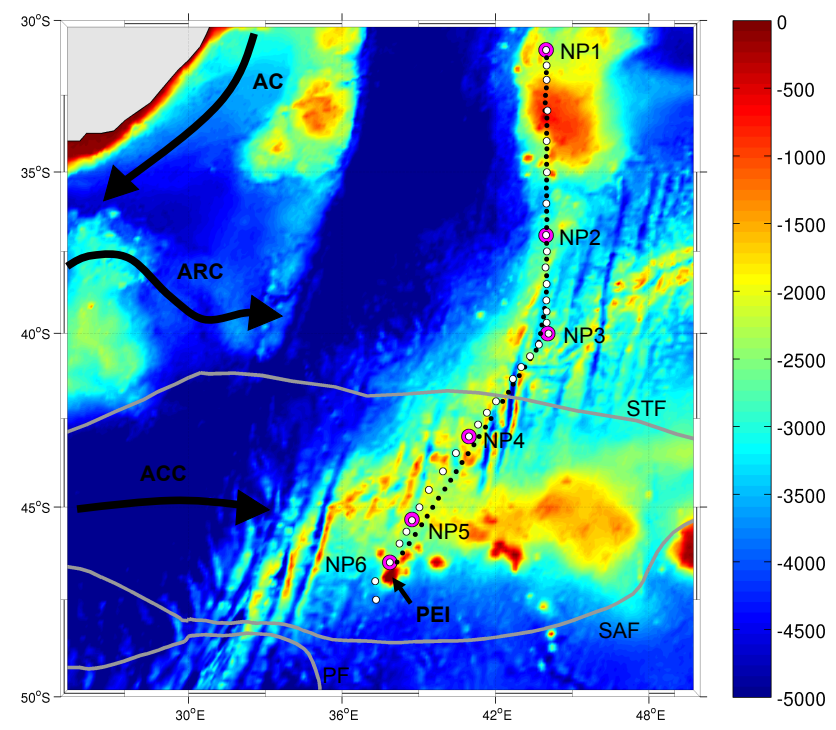

Fig. 1. Cruise tracks overlaid on bathymetry of the Northbound transect, showing XBT station positions as black dots. Together with the reciprocal Southbound transect, showing CTD station positions as white circles. The cruise tracks followed the Southwest Indian and Madagascar Ridge, between the Prince Edward Islands (PEI) and $31^{\circ} \mathrm{S}$. Productivity stations are shown as pink circles and labelled (NP1-NP6). Black arrows mark the position of the Agulhas current (AC), the Agulhas Return Current (ARC) and the Antarctic Circumpolar current (ACC). Grey lines indicate the mean frontal positions of the Sub Tropical Front (STF), the Sub Antarctic Front (SAF) and the Polar Front (PF) according to Orsi et al. (1995).

fore provides a unique location in which to explore the relationships between nutrient and hydrographic controls of phytoplankton distribution and new production. This study aims to identify and characterise different hydrographic regimes wherein the observed phytoplankton distribution and production is interpreted in terms of both the physical and biogeochemical control mechanisms regulating phytoplankton growth. Regions of enhanced biomass and production are similarly investigated in order to better understand the relationship between the physical forcing mechanisms responsible for an improved biological response.

\section{Sampling and analytical methods}

The Prince Edward Island archipelago, comprising Marion and Prince Edward Islands, lies due south of Africa within the subantarctic zone at latitude $46^{\circ} \mathrm{S}$ and longitude $37^{\circ} \mathrm{E}$. A five-year Marion Island Oceanographic Survey (MIOS) of the island region was run between 1996 and 2000 using the M/V SA Agulhas. The survey consisted of routine annual underway transects (April/May; at the end of the austral summer) between Cape Town and the islands to determine the variability and biological signature of meandering fronts in this region of the Southern Ocean (Pakhomov et al., 1998). 
During the 1999 cruise (MIOS 4), an additional northbound and a reciprocal southbound transect followed the Southwest Indian and Madagascar Ridge, between the Prince Edward Islands and $31^{\circ} \mathrm{S}$ (Fig. 1). Associated with this physical survey, measurements of chlorophyll- $a$ (chl- $a$ ), nutrient concentrations and phytoplankton nitrogen uptake were also performed.

\subsection{Northbound transect}

During the northbound transect, the water column temperature structure was determined from 68 Sippican T-7 (to $760 \mathrm{~m}$ ) XBT deployments at $15^{\prime}$ latitude intervals (Fig. 1). Temperature profiles were plotted as sections in Ocean Data View (ODV) (Schlitzer, 2002) to locate the frontal positions and hence plan the CTD station spacing for the southbound leg. To identify the major features along the Madagascar Ridge section, the definitions of the frontal positions outlined by Park et al. (1993) were adopted. They defined these features using the subsurface $(200 \mathrm{~m})$ cross frontal ranges of temperature. The fronts were identified as the maximum gradient in a temperature range from $12-16^{\circ} \mathrm{C}$ for the $\mathrm{AF}, 8$ $12^{\circ} \mathrm{C}$ for the STF and $4-8^{\circ} \mathrm{C}$ for the SAF. On this northbound transect, surface samples were taken for total and size fractionated chl- $a$ determinations.

\subsection{Southbound transect}

The southbound section consisted of 33 CTD profiles (to $\sim 2000 \mathrm{~m}$ ) that were worked close to the crest of the ridge running south from Madagascar to the crest of the Southwest Indian Ridge before turning south-west and terminating west of the Prince Edward Islands (Fig. 1). Station spacing varied from $1^{\circ}$ over the subtropical gyre between $31^{\circ}$ and $37^{\circ} \mathrm{S}$ to every $20^{\prime}$ latitude over the frontal regions. Water samples were collected from 12 standard depths between $2000 \mathrm{~m}$ and the surface. Productivity stations were carried out at selected locations (Fig. 1, NP1-NP6) where a second CTD cast was deployed and samples collected from six light depths. For each production station, the light depths were calculated from light attenuation (Kirk, 1994) estimated by Secchi disk due to a malfunctioning underwater PAR sensor. The extinction coefficient Kd was used to calculate the 100, 50, 25, 10, 1 and $0.1 \%$ light depths from:

$Z(x \%)=\frac{Z(\mathrm{sd})}{1.44(-\ln (x / 100))}$

Where: $Z(x \%)$ is the depth $(\mathrm{m})$ of a particular light level $(x \%), Z(\mathrm{sd})$ is the Secchi depth (m) and $x$ is the light level to be determined.

\subsection{Chlorophyll- $a$}

Samples from six standard depths to $150 \mathrm{~m}$ were prescreened through a $200 \mu \mathrm{m}$ mesh to exclude zooplankton grazers, after which they were gently filtered $(<$
$5 \mathrm{~cm} \mathrm{Hg}$ ) through a serial filtration unit and fractionated into pico- $(<2.0 \mu \mathrm{m})$, nano- $(2-20 \mu \mathrm{m})$ and micro-phytoplankton $(>20-200 \mu \mathrm{m})$ size fractions and collected on $25 \mathrm{~mm}$ Whatman GF/F filters. After extraction in $90 \%$ acetone for $24 \mathrm{~h}$, chl- $a$ was measured on an AU-10 Turner Designs fluorometer, calibrated against a standard chl- $a$ solution (Sigma).

\subsection{Nutrients}

For each productivity station, on board analyses of ammonium and urea were carried out in triplicate for each light depth according to the manual method described in Grasshoff et al. (1983), but scaled down to $5 \mathrm{ml}$ sample volumes. The method for ammonium analyses covers the range $0.05-$ $150 \mathrm{mmol} \mathrm{m}^{-3}$ with a relative standard deviation of $\pm 4.8 \%$ (Grasshoff et al., 1983). The range of the urea method is $1-10 \mathrm{mmol} \mathrm{m}^{-3}$, the precision at $2 \mathrm{mmol} \mathrm{m}^{-3}$ is $\pm 4.5 \%$ whereas at the $0.5 \mathrm{mmol} \mathrm{m}^{-3}$ the coefficient of variation is estimated to be $\pm 15 \%$ (Grasshoff et al., 1983). A $15 \mathrm{ml} \mathrm{sam-}$ ple from every depth was stored frozen for later nutrient analysis back at the University of Cape Town (UCT) where manual analyses were performed for $\mathrm{NO}_{3}$ and $\mathrm{Si}(\mathrm{OH})_{4}$ according to the methods described in Grasshoff et al. (1983) and Parsons et al. (1984), but scaled to a $5 \mathrm{ml}$ sample size. If no systematic sampling errors are involved, the relative accuracy of the $\mathrm{NO}_{3}$ determinations is $\pm 3 \%$ in the $0-10 \mathrm{mmol} \mathrm{m}^{-3}$ range (Grasshoff et al., 1983). The range for $\mathrm{Si}(\mathrm{OH})_{4}$ determinations is $0.1-200 \mathrm{mmol} \mathrm{m}^{-3}$, the precision at $4.5 \mathrm{mmol} \mathrm{m}^{-3}$ is $\pm 4 \%$ and $\pm 2.5 \%$ at $45 \mathrm{mmol} \mathrm{m}^{-3}$ (Grasshoff et al., 1983).

\section{$2.5 \quad{ }^{15} \mathrm{~N}$ incubations}

Bulk water samples were obtained from each of the six light depths and dispensed into three $2 \mathrm{~L}$ acid cleaned glass Schott bottles for $\mathrm{NO}_{3}^{-}, \mathrm{NH}_{4}^{+}$and urea uptake measurements. Spikes at $\sim 10 \%$ of ambient concentration for ${ }^{15} \mathrm{~N}-\mathrm{NO}_{3}$, ${ }^{15} \mathrm{~N}_{-} \mathrm{NH}_{4}$ and ${ }^{15} \mathrm{~N}$-urea were added to one of each of the three $2 \mathrm{~L}$ incubation bottles. As no on board measurements of $\mathrm{NO}_{3}$ were available, spikes were estimated according to different oceanic regimes using historical data (Schlitzer, 2000). The spiked samples were transferred to on-deck perspex tube incubators, screened with neutral density filters to simulate in situ light at the appropriate depths. The incubators were cooled with a constant supply of surface seawater to simulate in situ temperatures. In subantarctic stations, where mixed layers were isothermal to below the euphotic zone, no temperature differential is expected to affect uptake rates. However, in the subtropics, it is possible that subsurface samples are exposed to higher than ambient in situ temperatures. Although the effect of this temperature differential on phytoplankton uptake rates was not measured, one can expect it to be small. The samples were incubated for between 10$24 \mathrm{~h}$, centred around local midday. Isotopic-dilution of ${ }^{15} \mathrm{~N}-$ $\mathrm{NH}_{4}$ in particular by $\mathrm{NH}_{4}$ excretion in vitro will underestimate the computed $\mathrm{NH}_{4}$ uptake rates (Harrison and Harris, 
1986; Donald et al., 2001; Varela et al., 2005), particularly in oligotrophic oceans (Harrison and Harris, 1986). Uptake experiments were terminated by filtration onto ashed $47 \mathrm{~mm}$ $\mathrm{GF} / \mathrm{F}$ filters that were then stored at $-20^{\circ} \mathrm{C}$ for later analysis at the Plymouth Marine Laboratory (PML) for particulate nitrogen and atom $\%{ }^{15} \mathrm{~N}$ analyses on a Europa Tracermass continuous flow mass spectrometer (Europa Scientific Ltd.) using methods described by Barrie et al. (1989) and Owens and Rees (1989).

Nitrate, urea and ammonium uptake rates were calculated according to Dugdale and Goering (1967):

$\rho \mathrm{NO}_{3}, \rho \mathrm{NH}_{4}$ and $\rho$ urea $\left(\mathrm{mmol} \mathrm{m}^{-3} \mathrm{~h}^{-1}\right)=(\mathrm{PE} \times \mathrm{PN}) /\left(R_{0} \times T\right)$

Where PE $=\%{ }^{15} \mathrm{~N}$ enrichment of the PON fraction in excess of the natural abundance; $\mathrm{PN}=$ particulate $\mathrm{N}$ concentration $\left(\mathrm{mmol} \mathrm{m}^{-3}\right) ; T=$ experimental duration (h) and $R_{0}$ is the calculated aqueous ${ }^{15} \mathrm{~N}$ enrichment at time zero.

\section{Results}

\subsection{Northbound Transect}

\subsubsection{Temperature distribution and frontal positions}

On the Northbound transect, the AF was positioned at approximately $40^{\circ} \mathrm{S}$, while the STF was located at $43.5^{\circ} \mathrm{S}$ (Fig. 2a), further south than the range given by Lutjeharms and Valentine (1984). The SAF was located at $45.5^{\circ} \mathrm{S}$. The bottom topography (Fig. 2b) illustrates the extent to which the ridge shallows in certain places $(<1000 \mathrm{~m})$.

\subsubsection{Chlorophyll distribution}

North of the AF, chl- $a$ concentrations did not exceed $\sim 0.2 \mathrm{mg} \mathrm{m}^{-3}$, while south of the $\mathrm{AF}$, maximum concentrations of $0.4 \mathrm{mg} \mathrm{m}^{-3}$ were associated with the STF (Fig. 2c). There was no marked change in chl- $a$ concentrations within the SAF region, although at $\sim 46^{\circ} \mathrm{S}$, in the shallow $(<1000 \mathrm{~m})$ region of the Prince Edward Island plateau, chl- $a$ concentrations rose sharply to $\sim 1.6 \mathrm{mg} \mathrm{m}^{-3}$. Nanoand pico-phytoplankton dominated $(93 \%)$ phytoplankton biomass throughout the transect, except over the plateau where micro-phytoplankton dominated (81\%) (Fig. 2d).

\subsection{Southbound transect}

\subsubsection{General hydrography}

On the Southbound transect, the position of the AF $\left(40^{\circ} \mathrm{S}\right)$ was similar to that found on the northbound leg, however it had now merged with the STF which had migrated equatorward during the intervening ten days. On this transect the STF could be placed at the northern $\left(42.5^{\circ} \mathrm{S}\right)$ or southern $\left(43.25^{\circ} \mathrm{S}\right)$ edge of a transitional region where temperatures at

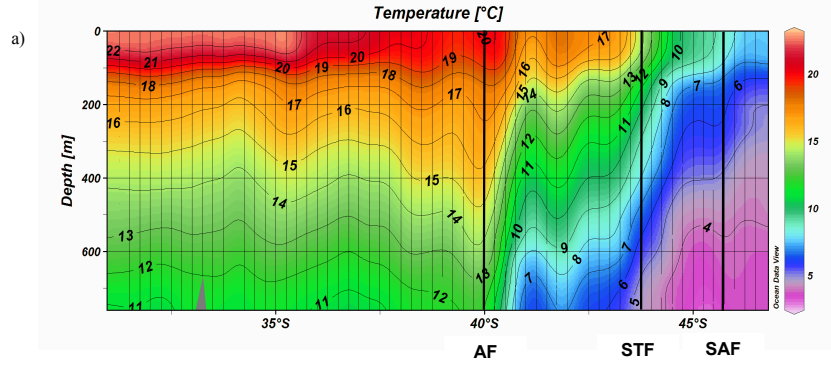

b)
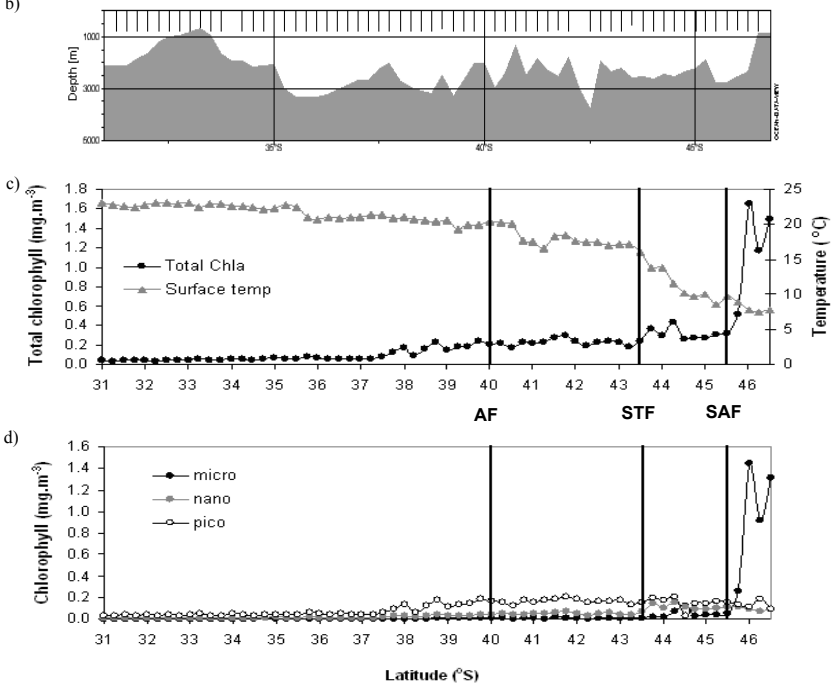

Fig. 2. (a) XBT temperature section during the Northbound Transect, data points for all XBT stations are marked and appear as vertical lines on the temperature section, (b) topography section shows the position and depth of each XBT station, (c) surface chlorophyll $\left(\mathrm{mg} \mathrm{m}^{-3}\right)$ and sea surface temperature $\left({ }^{\circ} \mathrm{C}\right)$ distribution and $(\mathbf{d})$ size fractionated distribution $\left(\mathrm{mg} \mathrm{m}^{-3}\right)$ of surface chlorophyll along the Northbound Transect. The position of the Agulhas Front (AF), Subtropical Front (STF) and Subantarctic Front (SAF) are indicated as bold lines. Plots made using Ocean Data View (Schlitzer, 2002).

the base of the mixed layer $\left(\sim 12^{\circ} \mathrm{C}\right.$ at $\left.\sim 80 \mathrm{~m}\right)$ were significantly less than those of Agulhas $\left(15^{\circ} \mathrm{C}\right)$ or Subtropical (19$\left.20^{\circ} \mathrm{C}\right)$ Water but higher than Subantarctic Waters $\left(<9^{\circ} \mathrm{C}\right)$. The more northerly edge marks the greatest change in water mass characteristics and concurs with the definitions outlined by Park et al. (1993), hence the STF was placed at $42.5^{\circ} \mathrm{S}$ (Pakhomov et al., 1999).

South of $43^{\circ} \mathrm{S}$, no frontal features were obvious. The water masses are typical of the subantarctic region, but temperature and salinity showed considerable mesoscale structure at $\sim 200 \mathrm{~m}$ superimposed on the general regime (Fig. 3a and b). There is a sequence, from north to south, of cold, fresh $\left(44.5^{\circ} \mathrm{S}\right)$; warm, salty $\left(45.33^{\circ} \mathrm{S}\right)$; cold, fresh $\left(45.75^{\circ} \mathrm{S}\right)$; and warm, salty $\left(46^{\circ} \mathrm{S}\right)$ features. South of $46^{\circ} \mathrm{S}$ the mesoscale structures were no longer present and the temperature and salinity characteristics were those of Subantarctic Surface Water. 

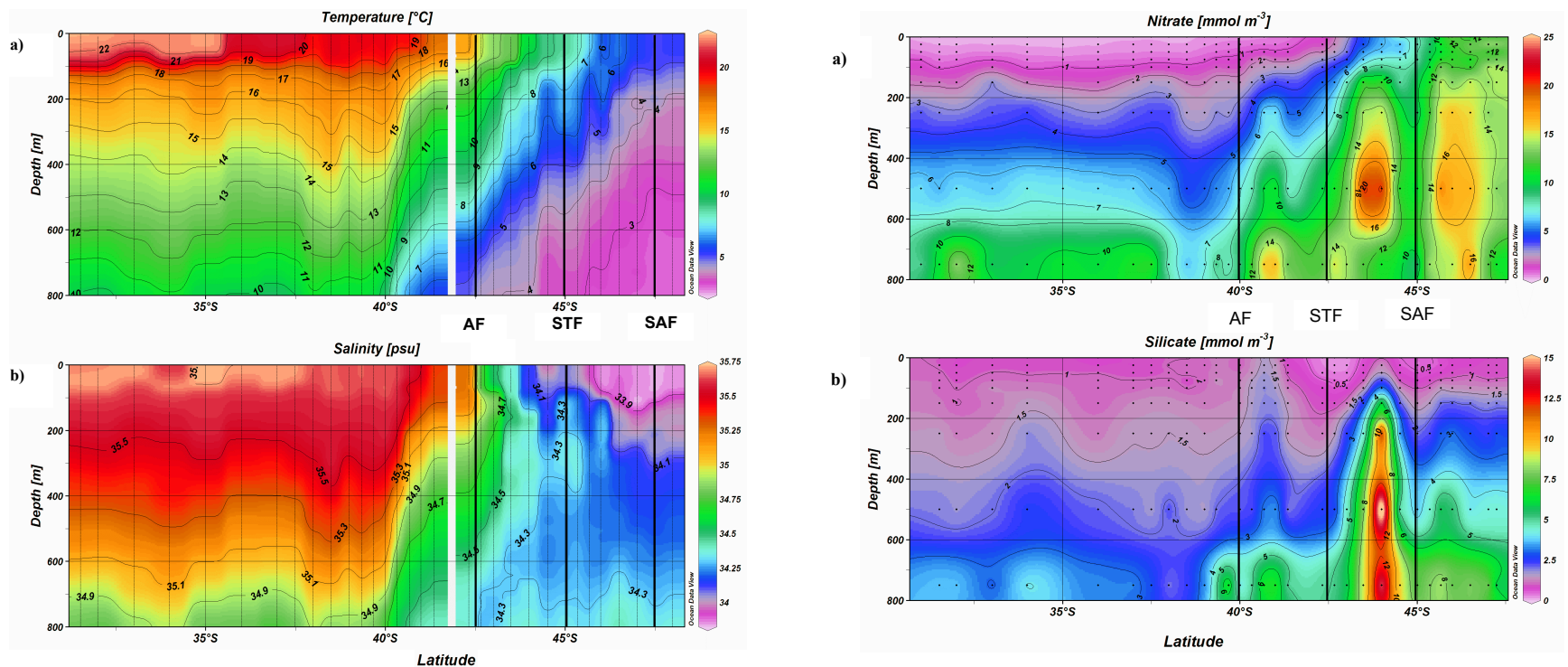

Fig. 3. CTD sections to $800 \mathrm{~m}$ of (a) temperature $\left({ }^{\circ} \mathrm{C}\right)$ and (b) salinity for the Southbound Transect between $31^{\circ} \mathrm{S}$ and the Prince Edward Islands, data points for all CTD stations are marked and appear as vertical lines on the temperature section. The position of the Agulhas Front (AF), Subtropical Front (STF) and Subantarctic Front (SAF) are marked as bold vertical lines. The white space represents a data gap in the CTD transect. Plots made using Ocean Data View (Schlitzer, 2002).

North of $45^{\circ} \mathrm{S}$ there is a subsurface salinity minimum $(\sim 300 \mathrm{~m})$ associated with subducting Antarctic Intermediate Water (AAIW). South of $45^{\circ} \mathrm{S}$ however, the lowest salinity water is in the surface layer and continues to decrease, reaching a minimum at the southern end of the section (Fig. 3b). According to Whitworth and Nowlin (1987), this change in vertical structure is the major identifier of the SAF, which for this transect is placed at $45^{\circ} \mathrm{S}$. The positioning of the SAF agrees with that of Pakhomov et al. (1999), who used definitions outlined by Park et al. (1993).

\subsubsection{Nutrient distribution}

A strong gradient of increasing surface nitrate concentration is evident with a progression from north to south across the region (Fig. 4a), concurrent with the decreasing temperature gradient (Fig. 3a). Nitrate values in subtropical surface waters are low $\left(0.01-0.49 \mathrm{mmol} \mathrm{m}^{-3}\right.$ in the surface $\left.50 \mathrm{~m}\right)$ and intensify southwards, with sharp increases in surface concentrations across the STF $\left(2-4 \mathrm{mmol} \mathrm{m}^{-3}\right)$ and SAF (8$\left.11 \mathrm{mmol} \mathrm{m}^{-3}\right)$. By contrast, surface silicate values remain low $\left(<2 \mathrm{mmol} \mathrm{m}^{-3}\right)$ throughout the transect, with minimum concentrations $\left(<1 \mathrm{mmol} \mathrm{m}^{-3}\right)$ at the STF and SAF (Fig. 4b). South of the SAF, surface $(<\sim 200 \mathrm{~m})$ nitrate concentrations rise to $12-14 \mathrm{mmol} \mathrm{m}^{-3}$, but $\mathrm{Si}$ concentrations remain low $\left(\sim 2 \mathrm{mmol} \mathrm{m}^{-3}\right)$. As expected, deeper waters below $\sim 200 \mathrm{~m}$ are characterised by increasing nutrient concentrations that rise steadily with depth.

Fig. 4. CTD sections of (a) nitrate $\left(\mathrm{mmol} \mathrm{m}^{-3}\right)$ and (b) silicate $\left(\mathrm{mmol} \mathrm{m}{ }^{-3}\right.$ ) for the Southbound Transect to $800 \mathrm{~m}$. Data points are indicated as black dots. The position of the Agulhas Front (AF), Subtropical Front (STF) and Subantarctic Front (SAF) are marked as bold vertical lines. Plots made using Ocean Data View (Schlitzer, 2002).

Ambient nitrate, ammonium and urea concentrations from the six productivity stations are integrated over the euphotic zone (1\% for NP1 and $0.1 \%$ for NP2-NP6) and represented as a percentage of the total nitrogen pool $\left(\mathrm{NO}_{3}+\mathrm{NH}_{4}+\right.$ urea) (Fig. 5a-f). In subtropical waters (NP1-NP3) integrated $\mathrm{NO}_{3}$ ranges from $\sim 20$ to $60 \mathrm{mmol} \mathrm{m}^{-2}$ and comprises $20-30 \%$ of the total $\mathrm{N}$ pool. Further south, beyond the $\mathrm{SAF}, \mathrm{NO}_{3}$ concentrations continue to increase with latitude to a maximum of $1075 \mathrm{mmol} \mathrm{m}^{-2}$ at the southern most station (NP6), where it constitutes $94 \%$ of total N. Conversely, ambient urea decreased with southerly latitude, from a maximum in the north (NP1, $130.2 \mathrm{mmol} \mathrm{m}^{-2} ; 68 \%$ of total $\mathrm{N}$ ), to a minimum in the south (NP6, $11.5 \mathrm{mmol} \mathrm{m}^{-2}$; just $1 \%$ of total N). Ambient $\mathrm{NH}_{4}^{+}$concentrations were variable and displayed no obvious spatial trends. Station NP1 had the lowest ambient $\mathrm{NH}_{4}^{+}\left(2.2 \mathrm{mmol} \mathrm{m}^{-2}\right)$, and comprised just over $1 \%$ of total $\mathrm{N}$. The highest integrated values of $39.2 \mathrm{mmol} \mathrm{m}^{-2}$ and $59.9 \mathrm{mmol} \mathrm{m}^{-2}$ were found at the AF (NP3) and over the Prince Edward Island plateau (NP6).

\subsubsection{Chlorophyll distribution}

The unfractionated (total) chl- $a$ section for the water column $(150 \mathrm{~m})$ shows very low chl- $a$ concentrations $(<0.1-$ $\left.0.2 \mathrm{mg} \mathrm{m}^{-3}\right)$ in subtropical waters north of the STF and a deep (but still low) subsurface maximum $\left(\sim 0.2 \mathrm{mg} \mathrm{m}^{-3}\right)$ at $\sim 75 \mathrm{~m}$ (Fig. 6a). South of the STF, total chl- $a$ distribution showed considerable variation with a series of higher and lower concentrations. These changes in chl- $a$ 

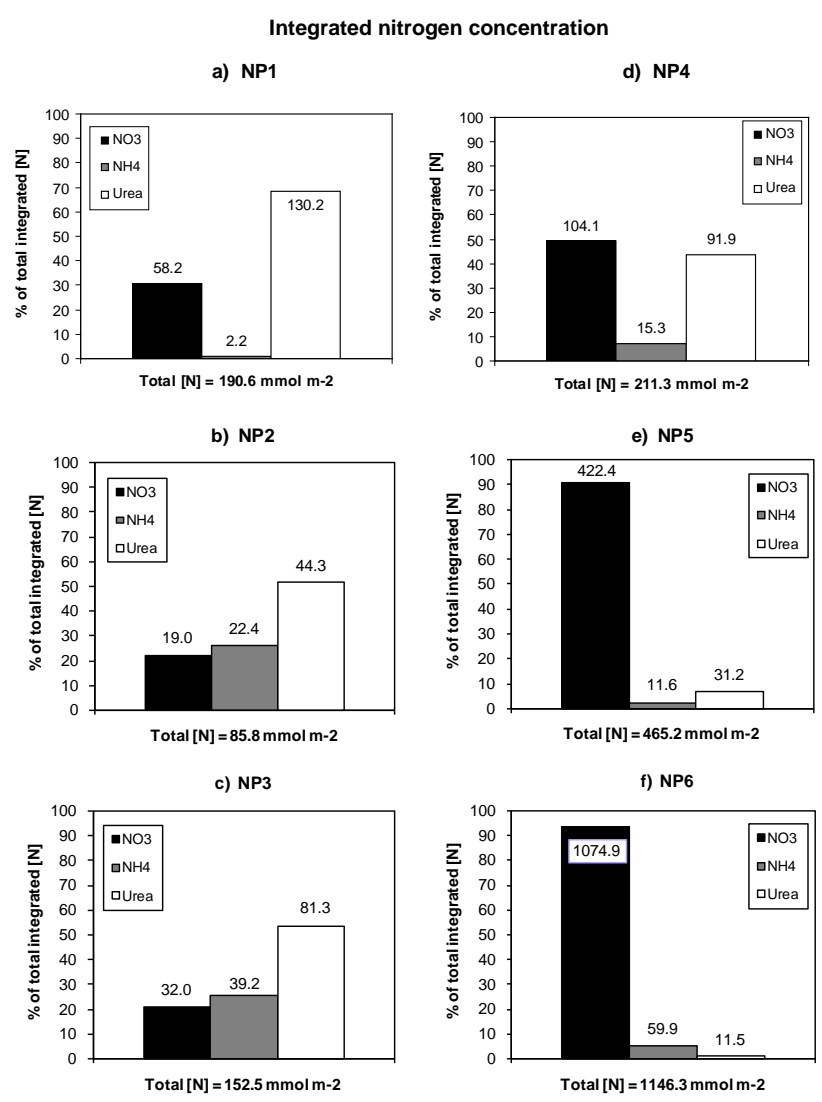

Fig. 5. (a-f) Nitrate, ammonium and urea $\left(\mathrm{mmol} \mathrm{m}^{-2}\right)$ concentrations integrated (to the $1 \%$ light depth for NP1 and $0.1 \%$ for NP2-NP6) and represented as a percentage of the total ambient nitrogen $\left(\mathrm{NO}_{3}+\mathrm{NH}_{4}+\right.$ urea), for each of the six productivity stations. Numbers at the top of each bar represent the integrated nutrient concentration for each nutrient, with the total $\mathrm{N}$ concentration $\left(\mathrm{NO}_{3}+\mathrm{NH}_{4}+\right.$ urea $)$ at the bottom of each figure.

appear to be related to the temperature and salinity structure (Fig. 3a and b), with enhanced biomass coinciding with cold, fresh waters and vice versa. Enhanced chl- $a$ concentrations were strongly coincident with all three frontal regions; i.e. the $\mathrm{AF}\left(\sim 0.2 \mathrm{mg} \mathrm{m}^{-3}\right)$, the STF $\left(\sim 0.4 \mathrm{mg} \mathrm{m}^{-3}\right)$, SAF $\left(\sim 0.7 \mathrm{mg} \mathrm{m}^{-3}\right)$ as well as over the Prince Edward Island plateau $\left(\sim 0.74 \mathrm{mg} \mathrm{m}^{-3}\right)$. These peaks in chl- $a$ concentration were evident in all three size fractions (Fig. 6b). Picophytoplankton are ubiquitous and the dominant size fraction on the transect apart from at the SAF and the Prince Edward Island Plateau, where micro-phytoplankton dominate (Fig. 6b).

Size fractionated chl- $a$ concentrations for the six productivity stations are integrated over the euphotic zone (1\% for NP1 and $0.1 \%$ for NP2-NP6) and represented as a percentage of total integrated chl- $a$ (Fig. 7a-f). As chl- $a$ concentrations were collected at standard depths as opposed to \% light depths, the chl- $a$ concentration at $0.1 \%$ light (1\% for NP1) had to be interpolated to allow a euphotic zone inte-
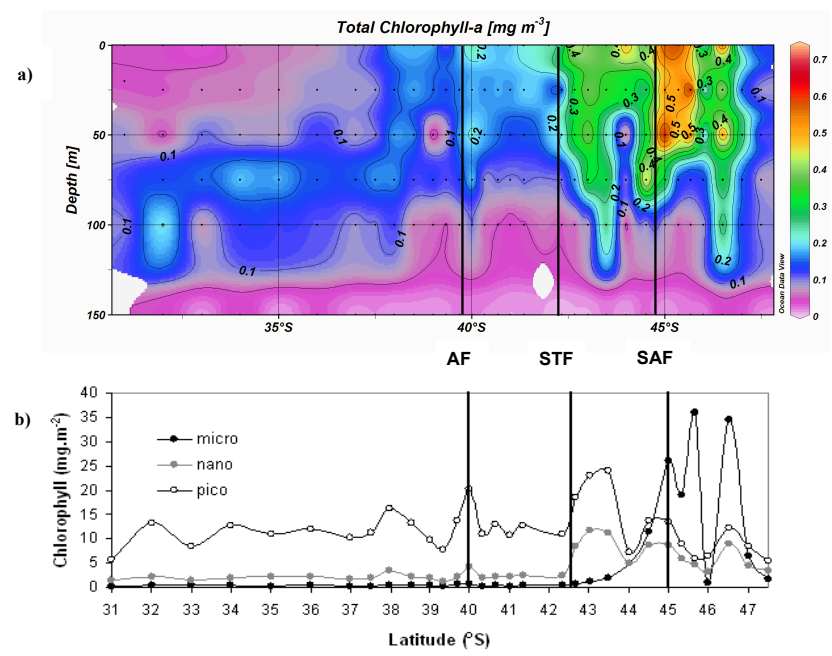

Fig. 6. (a) CTD total chlorophyll $\left(\mathrm{mg} \mathrm{m}^{-3}\right)$ section to $150 \mathrm{~m}$ with data points indicated as black dots and (b) size fractionated chlorophyll distribution $\left(\mathrm{mg} \mathrm{m}^{-3}\right)$ integrated over the top $150 \mathrm{~m}$ for the Southbound Transect. The position of the three frontal systems are marked as bold vertical lines. The section was made using Ocean Data View (Schlitzer, 2002).

gration. Within subtropical waters (NP1, NP2), total chl- $a$ biomass was low $\left(7.5\right.$ and $\left.8.6 \mathrm{mg} \mathrm{m}^{-2}\right)$ and dominated by pico-phytoplankton $(\sim 80 \%)$. Micro-phytoplankton on the other hand only accounted for $2-4 \%$ of total chl- $a$ (Fig. 7a and $b$ ). The AF (NP3) was marked by a sharp increase in biomass to $19.6 \mathrm{mg} \mathrm{m}^{-2}$, but with little change in community structure (Fig. 7c). At the STF (NP4), biomass increased slightly with a shift towards nano-phytoplankton $(\sim 33 \%)$, the highest percentage recorded (Fig. 7d). Further south at stations NP5 and NP6, biomass rose to $\sim 26$ and $45 \mathrm{mg} \mathrm{m}^{-2}$ respectively, and is attributable to larger micro- phytoplankton that dominated the community, accounting for $58.6 \%$ and $61.4 \%$ of total chl- $a$ (Fig. 7e and f). The pico- $(\sim 22 \%)$ and nano-phytoplankton $(\sim 16 \%)$ size classes followed in relative abundance.

\subsubsection{Nitrogen uptake}

Nutrient $\left(\mathrm{NO}_{3}^{-}, \mathrm{NH}_{4}^{+}\right.$, urea) uptake data $(\rho \mathrm{N})$ are presented for the nominal euphotic zone to the $0.1 \%$ light depth ( $1 \%$ for Station NP1) (Table 1). $\rho \mathrm{N}$ uptake rates were typically highest in surface (NP1, NP2, NP6) or subsurface (NP3, NP4, NP5) waters and decreased with depth to minimum values at the base of the euphotic layer (Table 1). $\rho \mathrm{N}$ uptake rates were integrated to the $0.1 \%$ light depth for four of the six productivity stations (NP2-NP5). Exceptions occur at stations NP1 where data at the $0.1 \%$ light depth is absent and station NP6, where regenerated uptake rates were relatively low at the $0.1 \%$ light depth, compared to the remaining water column and new production rates relatively high, resulting in an unrealistic f-ratio for this depth (0.83). Uptake rates for 
Table 1. Nitrate, ammonium and urea concentrations $\left(\mathrm{mmol} \mathrm{m}^{-3}\right)$, uptake rates $\left(\mathrm{mmol} \mathrm{m}^{-3} \mathrm{~d}^{-1}\right)$ and f-ratios at the various light depths for the productivity stations of the Southbound Transect, together with total chlorophyll $\left(\mathrm{mg} \mathrm{m}^{-3}\right)$ at set depths in the top $150 \mathrm{~m}$.

\begin{tabular}{|c|c|c|c|c|c|c|c|c|c|c|c|}
\hline $\begin{array}{l}\text { Station } \\
\text { Number }\end{array}$ & $\%$ Light & $\begin{array}{l}\text { Depth } \\
\text { (m) }\end{array}$ & $\begin{array}{r}\text { Ambient } \\
{\left[\mathrm{NO}_{3}\right]} \\
\left(\mathrm{mmol} \mathrm{m}^{-3}\right)\end{array}$ & $\begin{array}{r}\text { Ambient } \\
{\left[\mathrm{NH}_{4}\right]} \\
\left(\mathrm{mmol} \mathrm{m}^{-3}\right)\end{array}$ & $\begin{array}{r}\text { Ambient } \\
{[\text { Urea }]} \\
\left(\mathrm{mmol} \mathrm{m}^{-3}\right)\end{array}$ & $\begin{array}{r}\mathrm{NO}_{3} \\
\text { Uptake } \\
\left(\mathrm{mmol} \mathrm{m}^{-3} \mathrm{~d}^{-1}\right)\end{array}$ & $\begin{array}{r}\mathrm{NH}_{4} \\
\text { Uptake } \\
\left(\mathrm{mmol} \mathrm{m}^{-3} \mathrm{~d}^{-1}\right)\end{array}$ & $\begin{array}{r}\text { Urea } \\
\text { Uptake } \\
\left(\mathrm{mmol} \mathrm{m}^{-3} \mathrm{~d}^{-1}\right)\end{array}$ & f-ratio & $\begin{array}{l}\text { Depth } \\
\qquad(\mathrm{m})\end{array}$ & $\begin{array}{r}\text { Total } \\
\text { Chlorophyll } \\
\left(\mathrm{mg} \mathrm{m}^{-3}\right)\end{array}$ \\
\hline \multirow[t]{5}{*}{ NP1 } & 100 & 0 & 0.06 & 0.03 & 1.59 & 0.01 & 0.13 & 0.58 & 0.02 & 0 & 0.05 \\
\hline & 50 & 15 & 0.13 & 0.03 & 1.10 & 0.02 & 0.06 & 0.23 & 0.07 & 20 & 0.05 \\
\hline & 25 & 26 & 0.18 & 0.03 & 1.03 & 0.01 & 0.06 & 0.22 & 0.04 & 50 & 0.09 \\
\hline & 10 & 50 & 0.18 & 0.01 & 1.38 & 0.01 & 0.05 & 0.23 & 0.03 & 100 & 0.09 \\
\hline & 1 & 99 & 1.89 & 0.03 & 1.45 & 0.04 & 0.06 & 0.10 & 0.18 & & \\
\hline \multirow[t]{6}{*}{ NP2 } & 100 & 0 & 0.01 & 1.22 & 2.5 & 0.04 & 1.07 & 0.39 & 0.02 & 0 & 0.09 \\
\hline & 50 & 9 & 0.1 & 0.12 & 0.83 & 0.01 & 0.12 & 0.09 & 0.05 & 25 & 0.09 \\
\hline & 25 & 15 & 0.16 & 0.41 & 0.17 & 0.01 & 0.18 & 0.05 & 0.06 & 50 & 0.08 \\
\hline & 10 & 29 & 0.24 & 0.29 & 0.17 & 0.00 & 0.15 & 0.02 & 0.01 & 75 & 0.15 \\
\hline & 1 & 58 & 0.17 & 0.17 & 0.67 & 0.01 & 0.17 & 0.07 & 0.04 & 100 & 0.08 \\
\hline & 0.1 & 86 & 0.47 & 0.06 & 0.17 & 0.01 & 0.13 & 0.02 & 0.08 & 150 & 0.01 \\
\hline \multirow[t]{6}{*}{ NP3 } & 100 & 0 & 0.06 & 0.68 & 0.79 & 0.08 & 0.61 & 0.42 & 0.07 & 0 & 0.27 \\
\hline & 50 & 9 & 0.16 & 0.68 & 1.53 & 0.07 & 0.49 & 0.83 & 0.05 & 25 & 0.19 \\
\hline & 25 & 15 & 0.22 & 0.41 & 0.84 & 0.20 & 0.53 & 0.61 & 0.15 & 50 & 0.24 \\
\hline & 10 & 29 & 0.33 & 0.41 & 1.58 & 0.10 & 0.35 & 0.84 & 0.08 & 75 & 0.25 \\
\hline & 1 & 58 & 0.44 & 0.47 & 0.74 & 0.10 & 0.44 & 0.23 & 0.13 & 100 & 0.12 \\
\hline & 0.1 & 86 & 0.63 & 0.34 & 0.2 & 0.04 & 0.35 & 0.03 & 0.08 & 150 & 0.02 \\
\hline \multirow[t]{6}{*}{ NP4 } & 100 & 0 & 2.13 & 0.28 & 0.76 & 0.03 & 0.16 & 0.18 & 0.08 & 0 & 0.38 \\
\hline & 50 & 5 & 2.1 & 0.17 & 0.76 & 0.03 & 0.14 & 0.23 & 0.07 & 25 & 0.39 \\
\hline & 25 & 9 & 2.07 & 0.22 & 1.05 & 0.05 & 0.13 & 0.31 & 0.10 & 50 & 0.4 \\
\hline & 10 & 18 & 2.01 & 0.28 & 0.76 & 0.01 & 0.15 & 0.15 & 0.03 & 75 & 0.37 \\
\hline & 1 & 35 & 1.86 & 0.33 & 2.67 & 0.02 & 0.13 & 0.23 & 0.04 & 100 & 0.05 \\
\hline & 0.1 & 53 & 1.91 & 0.33 & 2.57 & 0.01 & 0.08 & 0.09 & 0.06 & 150 & 0.01 \\
\hline \multirow[t]{6}{*}{ NP5 } & 100 & 0 & 7.66 & 0.23 & 0.59 & 0.02 & 0.06 & 0.06 & 0.15 & 0 & 0.61 \\
\hline & 50 & 5 & 7.66 & 0.23 & 0.71 & 0.03 & 0.05 & 0.09 & 0.15 & 25 & 0.47 \\
\hline & 25 & 9 & 7.66 & 0.52 & 0.59 & 0.03 & 0.15 & 0.07 & 0.13 & 50 & 0.41 \\
\hline & 10 & 18 & 7.66 & 0.12 & 0.71 & 0.02 & 0.04 & 0.07 & 0.12 & 75 & 0.11 \\
\hline & 1 & 35 & 8.07 & 0.17 & 0.59 & 0.01 & 0.03 & 0.03 & 0.14 & 100 & 0.03 \\
\hline & 0.1 & 53 & 8.69 & 0.23 & 0.35 & 0.00 & 0.13 & 0.02 & 0.03 & 150 & 0.02 \\
\hline \multirow[t]{6}{*}{ NP6 } & 100 & 0 & 7.84 & 0.72 & 0.29 & 0.09 & 0.87 & 0.24 & 0.07 & 0 & 0.63 \\
\hline & 50 & 10 & 10.51 & 0.67 & 0.11 & 0.11 & 0.57 & 0.21 & 0.12 & 25 & 0.46 \\
\hline & 25 & 17 & 12.39 & 0.58 & 0.11 & 0.20 & 0.62 & 0.13 & 0.21 & 50 & 0.57 \\
\hline & 10 & 32 & 14.71 & 0.63 & 0.11 & 0.11 & 0.61 & 0.11 & 0.13 & 75 & 0.36 \\
\hline & 1 & 64 & 10.29 & 0.63 & 0.11 & 0.04 & 0.26 & 0.04 & 0.13 & 100 & 0.31 \\
\hline & 0.1 & 96 & 8.44 & 0.58 & 0.11 & 0.19 & 0.03 & 0.01 & $(0.83)$ & 150 & 0.05 \\
\hline
\end{tabular}

these two stations were therefore only integrated to the $1 \%$ light depth. Integrated $\mathrm{N}$ uptake rates $\left(\int \rho \mathrm{N}\right)$ illustrate the overall significance and percent contribution of each nutrient within the euphotic layer (Fig. 8a-f). Despite having the lowest mean total chl- $a$ concentrations $\left(\sim 8 \mathrm{mg} \mathrm{m}^{-2}\right)$, the mean $\int \rho \mathrm{N}$ rate at stations NP1 and NP2 was surprisingly high, attaining 29.9 and $23.7 \mathrm{mmol} \mathrm{m}^{-2} \mathrm{~d}^{-1}$ respectively (Fig. 8a and b). Urea and $\mathrm{NH}_{4}$ dominated $\int \rho \mathrm{N}$, together contributing $\sim 94 \%$ of $\int \rho \mathrm{N}$, while $\int \rho \mathrm{NO}_{3}$ uptake $(\sim 6 \%)$ made only a minor contribution to the total. The AF (NP3) was marked by a tripling in water column $\int \rho \mathrm{N}$ to $84.61 \mathrm{mmol} \mathrm{m}^{-2} \mathrm{~d}^{-1}$ but this was still dominated by regenerated $\rho \mathrm{N}$ with $\int \rho$ urea and $\int \rho \mathrm{NH}_{4}$ contributing $\sim 46 \%$ and $\sim 44 \%$, respectively, to $\int \rho \mathrm{N}$ (Fig. 8c). The increased productivity is consistent with a doubling of chl- $a$ biomass to $19.6 \mathrm{mg} \mathrm{m}^{-2}$ relative to stations NP1 and NP2.

The STF station (NP4) did not fit the general trends. In spite of a similar total chl- $a$ biomass $\left(20.7 \mathrm{mg} \mathrm{m}^{-2}\right)$ to that at NP3 (AF), and an increase in ambient $\mathrm{NO}_{3}^{-}$concentra- tion $\left(104.1 \mathrm{mmol} \mathrm{m}^{-2}\right), \int \rho \mathrm{N}$ was low $\left(18.2 \mathrm{mmol} \mathrm{m}^{-2} \mathrm{~d}^{-1}\right)$ (Fig. 8d). Station NP5 within the SAF was also inconsistent, having the lowest $\int \rho \mathrm{N}\left(7.1 \mathrm{mmol} \mathrm{m}^{-2} \mathrm{~d}^{-1}\right)$ despite a high total chl- $a$ biomass $\left(25.8 \mathrm{mg} \mathrm{m}^{-2}\right)$ and a high ambient $\mathrm{NO}_{3}^{-}$ concentration $\left(422.4 \mathrm{mmol} \mathrm{m}^{-2}\right)$ (Fig. 8e).

Over the PE Island plateau (NP6), $\rho \mathrm{N}$ was marked by an increase in $\int \rho \mathrm{N}$ (to $48.9 \mathrm{mmol} \mathrm{m}^{-2} \mathrm{~d}^{-1}$ ). These high rates are consistent with the highest integrated chl$a$ value $\left(45.3 \mathrm{mg} \mathrm{m}^{-2}\right)$, which was dominated by microphytoplankton $(\sim 61 \%)$ (Fig. $8 \mathrm{f})$. Despite having a high micro-phytoplankton abundance, and the highest $\int \rho \mathrm{NO}_{3}$ of all the stations $(\sim 14 \%)$, total $\int \rho \mathrm{N}$ was still dominated by $\int \rho \mathrm{NH}_{4}(\sim 70.4 \%)$, while $\int \rho$ urea was of the same order as $\int \rho \mathrm{NO}_{3}$ and accounted for $\sim 16 \%$ of $\int \rho \mathrm{N}$. 

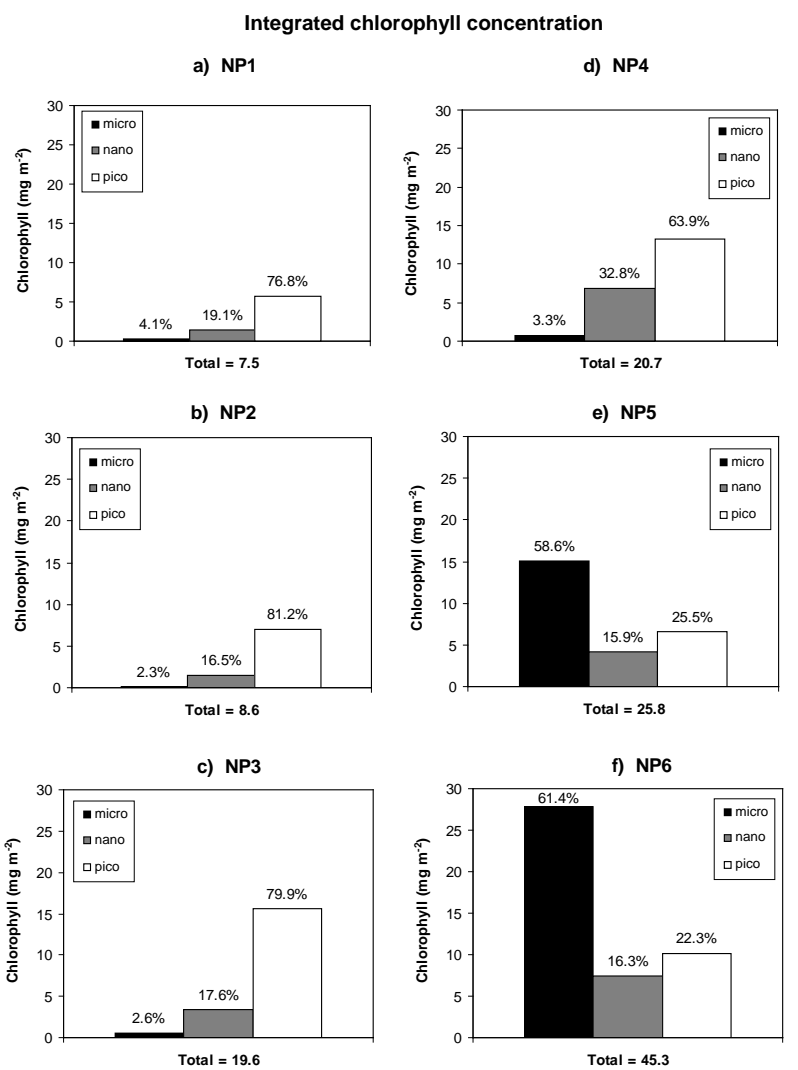

Fig. 7. (a-f). Euphotic zone integrated measurements (1\% for NP1 and $0.1 \%$ for NP2-NP6) of size-fractionated chlorophyll $\left(\mathrm{mg} \mathrm{m}^{-2}\right)$ represented as a percentage of total integrated chlorophyll for the six productivity stations on the Southbound Transect. Numbers at the top of each bar represent the percent contribution of each size fraction, with the total integrated chlorophyll concentration (micro + nano + pico) at the bottom of each figure.

\subsection{5 f-ratios}

At subtropical stations NP1-NP3, the f-ratio generally increased with depth, tracking ambient $\mathrm{NO}_{3}$ concentrations (Table 1). At the subantarctic stations NP4 and NP5, the situation was reversed and f-ratios generally decreased with depth, indicating a shift from $\int \rho \mathrm{NO}_{3}$ in surface waters to $\int \rho \mathrm{N}$ based primarily on reduced $\mathrm{N}$ at depth. The f-ratio's for station NP6, in relatively close proximity to the PE Islands however tended to increase with depth from a surface value of $\sim 0.07$ to 0.13 at the $1 \%$ light depth. The f-ratio at the $0.1 \%$ light depth $(96 \mathrm{~m})$ was rejected as an impossibly high value $(0.83)$. The integrated $\mathrm{f}$-ratio for this station is thus calculated from new and regenerated uptake rates integrated only to the $1 \%$ light depth (Fig. 9).

Integrated f-ratios (calculated from $\int \rho \mathrm{N}$ ), were very low (stations NP1-NP5 ranged from 0.04-0.11) indicative of very strong regeneration based production (Fig. 9). There is, however, a marginally increased reliance on $\rho \mathrm{NO}_{3}$ in waters adjacent to the PE Islands (NP6), where the f-ratio increased to a maximum of 0.14 .
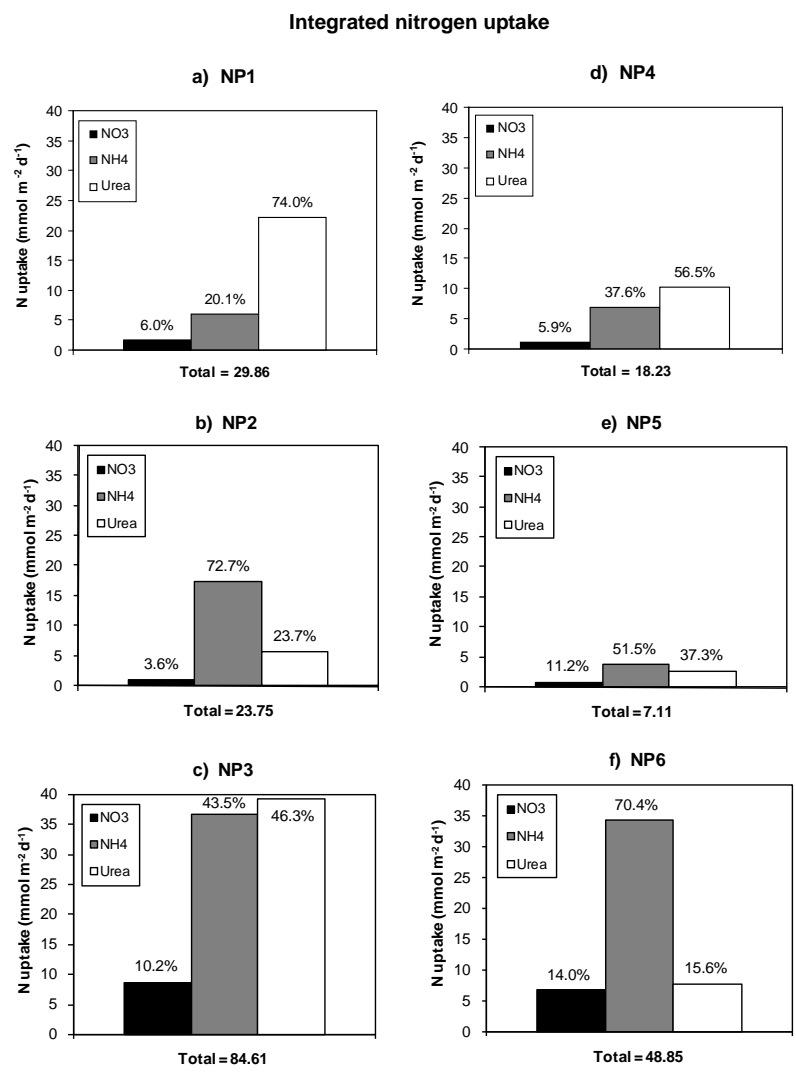

Fig. 8. (a-f). Euphotic zone (1\% for NP1 and NP6, 0.1\% for NP2NP5) integrated measurements of nitrate, ammonium and urea uptake $\left(\mathrm{mmol} \mathrm{m}^{-2} \mathrm{~d}^{-1}\right)$ represented as a percentage of total nitrogen uptake for the six productivity stations on the Southbound Transect. Numbers at the top of each bar represent the percent contribution of each nutrient, with total $\mathrm{N}$ uptake $\left(\mathrm{NO}_{3}+\mathrm{NH}_{4}+\right.$ urea) at the bottom of each figure.

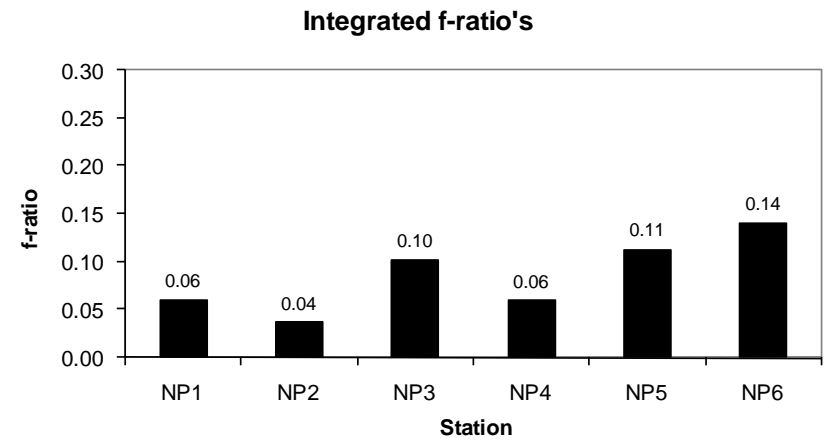

Fig. 9. Integrated f-ratios calculated from integrated euphotic zone ( $1 \%$ for NP1 and NP6, $0.1 \%$ for NP2-NP5) uptake rates for the six productivity stations of the Southbound Transect. 


\section{Discussion}

Our extensive latitudinal north-south transect to the south of Africa in late austral summer covered two hydrographically and biogeochemically distinct provinces, namely a subtropical region north of the STF and a subantarctic region south of the STF. Despite these distinctions, phytoplankton biomass was relatively uniform, but low, with only slight peaks in abundance observed at the frontal features and in the region of the Prince Edward Islands. Almost everywhere too, pico-phytoplankton dominated community structure except for south of the SAF where micro-phytoplankton dominated. Similarly, nitrogen uptake was also relatively low everywhere, with an overwhelming dominance by reduced nitrogen assimilation, as revealed by the exceedingly low fratios.

The lack of any isotopic dilution corrections for these experiments means that regenerated uptake measurements are underestimated, particularly for those stations where ambient $\mathrm{NH}_{4}$ concentrations bordered the limit of detection. Such underestimations of $\rho \mathrm{NH}_{4}$ by as much as a factor of two (Glibert et al., 1982) would further reduce the f-ratio, which raises questions over the sensitivities of the analytical techniques used to measure $\mathrm{NH}_{4}$ and urea concentrations. The commonly used indophenol blue method for $\mathrm{NH}_{4}$ analysis often yields inconsistent results, particularly when ammonium concentrations are low. The importance of $\rho \mathrm{NH}_{4}$ may therefore be distorted if ambient $\mathrm{NH}_{4}$ concentrations are overestimated and this needs to be considered when interpreting the results particularly with regards to the low f-ratios.

In the following discussion, we investigate phytoplankton distribution and primary production in the two distinct provinces where despite regional differences in physical forcing mechanisms, the biological responses were similar. In addition we examine the potential mechanisms responsible for regions of enhanced chl- $a$, changes in community structure and nitrogen dynamics that have a potentially significant impact on POC export and $\mathrm{CO}_{2}$ draw-down.

\subsection{Chlorophyll distribution and $\mathrm{N}$ assimilation north of the STF}

Hydrographic characteristics for this region in late austral summer consist of a shallow surface mixed layer $(\sim 75 \mathrm{~m})$ of warm, salty subtropical water, separated from deeper water by a strong seasonal thermocline (Fig. 3a). Such vertical stratification prevents the transport of deeper $\mathrm{NO}_{3}$ rich waters into the euphotic zone, except by shear or eddy diffusion, therefore accounting for low seasonal $\mathrm{NO}_{3}\left(<1 \mathrm{mmol} \mathrm{m}^{-3}\right)$ concentrations which are compounded by seasonal $\rho \mathrm{NO}_{3}$ that depletes the $\mathrm{NO}_{3}$ pool (Fig. 4a). Silicate concentrations here were also low $\left(<1.5 \mathrm{mmol} \mathrm{m}^{-3}\right)$ and likely to limit diatom frustule formation (Fig. 4b).

Maximal $\mathrm{NH}_{4}$ and urea concentrations (Fig. 5a-c) indicate that remineralisation rates exceeded nano- and pico-
Integrated chlorophyll-a normalised $\mathbf{N}$ uptake

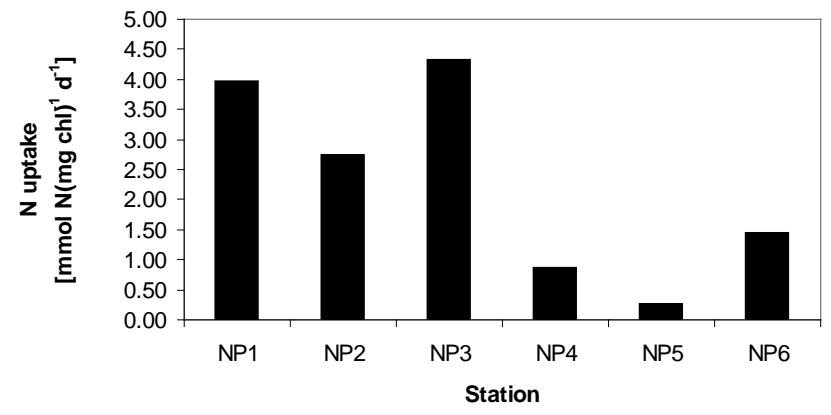

Fig. 10. Euphotic zone (1\% for NP1 and NP6, 0.1\% for NP2-NP5) integrated chlorophyll- $a$ normalized nitrogen uptake (mmol-at $\mathrm{N}$ $(\mathrm{mg} \mathrm{chl})^{-1} \mathrm{~d}^{-1}$ ) for the six productivity stations of the Southbound Transect.

phytoplankton uptake rates for these nutrients (Dugdale and Goering, 1967; Tremblay et al., 2000). Primary production by micro-phytoplankton was limited by both $\mathrm{NO}_{3}$ and silicate, thus paving the way for nano- and pico-phytoplankton dominated productivity based very strongly on regenerated $\mathrm{N}$, as indicated by exceedingly low f-ratios (Fig. 9). This region also exhibited the highest chl- $a$ normalised $\mathrm{N}$ uptake rates $\left(\rho \mathrm{N}^{*}\right)$ (Fig. 10). For stations NP1 to NP3, north of the STF, the mean integrated $\rho \mathrm{N}^{*}$ value was $>4$ times that of the three subantarctic stations (NP4-NP6). These results could suggest that combined $\rho \mathrm{N}$ and photosynthesis in the subantarctic is either Fe-limited or co-limited by Fe and light, where the latter encourages chl- $a$ packaging to compensate for lowered light intensities, therefore resulting in lowered $\rho \mathrm{N}^{*}$ values. Conversely, the region north of the STF appears to be freed from these influences. Without any Fe measurements, however, we are unable to substantiate this argument.

f-ratio values north of the STF increased with depth alongside elevated ambient $\mathrm{NO}_{3}$ concentrations (Table 1) indicating an increase in $\rho \mathrm{NO}_{3}$ with depth. This is unusual, although not unknown, since $\rho \mathrm{NO}_{3}$ is rather strongly light dependent and usually diminishes with depth (Lucas et al., 2007). It may be, therefore, that increasing $\rho \mathrm{NO}_{3}$ with depth, although potentially light limited, was offset by increasing $\mathrm{NO}_{3}$ concentrations, and conceivably increased Fe concentrations that facilitated both photosynthesis and intracellular nitrate reduction, although this is purely speculative. An alternative explanation is that increasing f-ratios with depth were consistent with a relative decrease in ambient $\mathrm{NH}_{4}$ and urea (Table 1).

High concentrations of regenerated nutrients result from micro-zooplankton grazing control (Froneman and Perissinotto, 1996), and although small size confers a competitive advantage for nutrients at low concentrations, it also increases susceptibility to grazing by micro-zooplankton (Raven, 1986), which controls their biomass but nevertheless 
contributes to potential phytoplankton production based on ammonium excretion (Glibert et al., 1992). Thus the turnover rate of nano- and pico-phytoplankton is closely coupled to micro-zooplankton grazing and low nutrient concentrations, which control phytoplankton biomass accumulation in the subtropical region north of the STF, as previously noted by Froneman and Perissinotto (1996) and Bathmann et al. (2000) amongst others. One consequence of this ecosystem structure is that $\mathrm{N}$ is conserved, but respiratory $\mathrm{CO}_{2}$ losses are high, and only a small fraction of the fixed POC is exported into deep water (Tremblay et al. 2000; Salter et al. 2007), not least because of the absence of any silicate ballasting effect (Thomalla et al., 2008; Sanders et al., 2010).

\subsection{Chlorophyll distribution and $\mathrm{N}$ assimilation south of the STF}

The absence of a strong thermocline in subantarctic waters reduces vertical stability and allows deeper nutrient rich water to be mixed into the surface layer. South of $43^{\circ} \mathrm{S}$ the temperature and salinity sections (Fig. $3 \mathrm{a}$ and $\mathrm{b}$ ) show considerable structure in a sequence from north to south. Whether these were mesoscale eddies, filaments, or larger frontal structures, is not possible to determine from a single section, however such structures have been observed previously (Read and Pollard, 1993) and attributed to eddies (e.g., Pollard and Regier, 1992). Such eddies would result in substantial heat loss and convective overturning that entrains nutrients into surface waters (Dower and Lucas, 1993; Pollard et al., 2002), with the potential to enhance primary production wherever stability and stratification occurs.

Despite high $\mathrm{NO}_{3}$ concentrations $\left(104-1074 \mathrm{mmol} \mathrm{m}^{-2}\right.$ ), primary production is still based primarily on regenerated nutrients as revealed by low f-ratios $(<0.5)$ (Fig. 9). Although the community structure exhibits a higher proportion of micro-phytoplankton, nano- and pico-phytoplankton still remain the dominant components (Fig. 6b). This scenario in Southern Ocean waters represents the now well-known high nutrient low chlorophyll (HNLC) paradox (Cullen, 1991) that is light-limited in winter and early spring, but Fe-limited in late spring and summer (Martin et al., 1989, 1991; de Baar et al., 1990, 2005; Moore et al., 2006, 2007a; Lucas et al., 2007; Cochlan, 2008). Fe limitation of phytoplankton productivity in the HNLC Southern Ocean has been well established through a series of in situ and naturally $\mathrm{Fe}$ fertilised experiments (Boyd et al., 2000, 2007; Gervais et al., 2002; Coale et al., 2004; Hoffmann et al., 2006; Blain et al., 2001, 2007; Pollard et al., 2009).

The increase in nutrient availability from reduced vertical stability is offset by a decrease in light availability with deep mixed layers. Irrespective of $\mathrm{Fe}$ availability, if the mixing depth exceeds the critical depth, phytoplankton growth becomes light limited (Nelson and Smith, 1991). Apart from light-limited photosynthesis, nitrate uptake is also restricted by low irradiance (Morel, 1991; Probyn et al., 1996;
Cochlan, 2008), as reflected here by the f-ratios, which decrease with depth (Table 1) because $\rho \mathrm{NO}_{3}$ is an energetically expensive and therefore light sensitive process (see discussion in Lucas et al., 2007). Low $\mathrm{Si}(\mathrm{OH})_{4}$ concentrations (Fig. 4b) are also likely to have limited diatom based new production south of the STF (see also Smetacek, 1998; Dugdale and Wilkerson 1998).

$\rho \mathrm{N}$ rates only increased in the region of the Prince Edward Island Plateau (station NP6, Fig. 8), where $\mathrm{Si}(\mathrm{OH})_{4}$ concentrations were elevated $\left(83 \mathrm{mmol} \mathrm{m}^{-2}\right)$ compared to stations NP4 $\left(2 \mathrm{mmol} \mathrm{m}^{-2}\right)$ and NP5 $\left(12 \mathrm{mmol} \mathrm{m}^{-2}\right)$ (data not shown) and where $\mathrm{Fe}$ concentrations were most likely also elevated due to the same mechanisms seen downstream of the Crozet archipelago (Pollard et al., 2009). Such elevated concentrations of $\mathrm{Si}$ and $\mathrm{Fe}$ are likely responsible for the micro-phytoplankton blooms found here (Fig. 7f).

\subsection{Regions of enhanced biomass and productivity}

The extent of the Southern Ocean makes it an area of great importance for the global ocean-atmosphere carbon balance despite its overall HNLC status. This is partly due to specific frontal, subantarctic island and ice-edge regions of the Southern Ocean that exhibit high seasonal rates of primary production; often by a diatom-dominated fraction (e.g. Bathmann et al., 2000; Tremblay et al., 2000; Atkinson et al., 2001; de Baar et al., 2005; Cochlan, 2008; Pollard et al., 2009). One result of this is that the Southern Ocean exports (to $1000 \mathrm{~m}$ ) the highest proportion $(\sim 3 \%)$ of its total production (Honjo et al., 2000), making it disproportionately important as a biologically mediated sink for atmospheric $\mathrm{CO}_{2}$.

\subsubsection{Enhanced biomass and productivity at ocean fronts}

In this study, elevated surface chl- $a$ concentrations coincided with frontal regions on both the Northbound and Southbound transects (Figs. 2c, 6a and b). All three peaks in chl- $a$ were strongly dominated by specific size classes, which suggest that the increase in biomass was probably the result of enhanced in situ production by selected components of the phytoplankton assemblage (Laubscher et al., 1993).

\section{The Agulhas Front}

The AF (NP3) was characterised by a doubling of chl$a$ biomass (Fig. 7c) and a 3-fold increase in water column $\mathrm{N}$ uptake (Fig. 8c) relative to adjacent non-frontal stations NP1 and NP2. However, $\int \rho \mathrm{N}\left(84.61 \mathrm{mmol} \mathrm{m}^{-2} \mathrm{~d}^{-1}\right)$ was still dominated $(\sim 90 \%)$ by regenerated $\int \rho$ urea and $\int \rho \mathrm{NH}_{4}$ despite integrated $\mathrm{NO}_{3}$ concentrations rising from $\sim 19$ (NP2) to $\sim 32 \mathrm{mmol} \mathrm{m}^{-2}$. Concurrently, the integrated f-ratio (Fig. 9) at NP3 was higher (0.10) than at NP1 (0.06) and NP2 (0.04).

The increased f-ratio within the AF implies a slight increase in $\rho \mathrm{NO}_{3}$ that could result from the observed increase 
in $\mathrm{NO}_{3}$ concentrations and/or from a more favourable light environment in the frontal region (Grundlingh, 1979; Lutjeharms et al., 1981, 1985).

This station exhibited the highest integrated $\rho \mathrm{N}^{*}$ value $\left(4.32 \mathrm{mmolN}\left(\mathrm{mg} \mathrm{chl}^{-1} \mathrm{~d}^{-1}\right)\right.$ of all productivity stations (Fig. 10), and implies that the dominant pico-phytoplankton ( $\sim 80 \%)$ (Fig. $7 \mathrm{c}$ ) are most likely out competing larger cells in scavenging the available $\mathrm{NO}_{3}$ because of typically low $\mathrm{Ks}$ values associated with small cells (Eppley et al., 1969).

\section{The Subtropical Front}

Previous studies of chl- $a$ distribution across frontal boundaries have shown the STF to have consistently high biomass and rates of biological activity (e.g., Weeks and Shillington, 1994; Barange et al., 1998) that result from cross-frontal mixing of nutrients and enhanced vertical stability (Plancke, 1977; Allanson et al., 1981; Lutjeharms, 1985). This study shows a peak in chl- $a$ concentration to the south of the STF (Fig. 6b and c) at station NP4, dominated by pico- (64\%) and nano-phytoplankton (33\%), while micro-phytoplankton are largely absent (3\%) (Fig. 7d). Nitrogen uptake within the community is based primarily on $\rho$ urea $(56.5 \%)$ and $\rho \mathrm{NH}_{4}$ (37.6\%) rather than on $\rho \mathrm{NO}_{3}$ (5.9\%) (Fig. 8d).

If elevated pigment concentrations associated with ocean fronts are the result of favourable dynamical conditions, then enhanced rates of primary production would indicate a thriving population. This was however not the case at $43^{\circ} \mathrm{S}$ (NP4), where productivity results show very low nutrient assimilation rates (Fig. 8d) and $\rho \mathrm{N}^{*}$ rates (Fig. 10). These rates reflect a phytoplankton population that is both nutrient and light limited with a mixed layer depth $(\sim 80 \mathrm{~m})$ that is well below the $0.1 \%$ light depth $(53 \mathrm{~m})$. Diatom growth at station NP4 would also be limited by very low integrated silicate values $\left(2.3 \mathrm{mmol} \mathrm{m}^{-2}\right)$. This station, situated one degree south of the STF, more likely represents a senescent phytoplankton population, the zone of peak production associated with the STF having migrated further north. On the Northbound transect 10 days previously, the STF was located at $43.5^{\circ} \mathrm{S}$ (Fig. 2a), the same position as station NP4. However, with the migration of the STF by one degree north $\left(42.5^{\circ} \mathrm{S}\right)$ on the Southbound transect (Fig. 3a), the favourable conditions associated with the front, that are responsible for initialising and essential in maintaining enhanced productivity are no longer present at station NP4 $\left(43.5^{\circ} \mathrm{S}\right)$.

\section{The Subantarctic Front}

A peak in integrated chl- $a$ concentration $\left(25.8 \mathrm{mg} \mathrm{m}^{-2}\right)$ coincides with the position of the SAF at $45^{\circ} \mathrm{S}$ (Fig. 6a and b). Total biomass is only slightly higher than at the AF and STF, however, the community structure is significantly different (Fig. 7e) and the first population to be dominated by the micro-phytoplankton size class (59\%).
Laubscher et al. (1993) concluded that microphytoplankton blooms associated with the SAF probably occur as a result of cross frontal mixing of silicate into the surface layer. In our study, the prominence of micro-phytoplankton at the SAF coincided with depleted silicate concentrations in the euphotic surface layer of $12.2 \mathrm{mmol} \mathrm{m}^{-2}$, compared to $83 \mathrm{mmol} \mathrm{m}^{-2}$ at station NP6 (data not shown). Combined with deep mixing and a low light environment (SML $>90 \mathrm{~m}, 0.1 \% 53 \mathrm{~m}$ ), it is not surprising that $\int \rho \mathrm{N}$ values $\left(7.1 \mathrm{mmol} \mathrm{m}^{-2}\right)$ and $\rho \mathrm{N}^{*}$ rates $\left(0.3 \mathrm{mmol} \mathrm{N}\left(\mathrm{mg} \mathrm{chl}^{-1} \mathrm{~d}^{-1}\right)\right.$ were low for this SAF station (Figs. 8e and 10).

\subsection{Enhanced biomass and $N$ uptake in the vicinity of the Prince Edward Islands}

Total chl- $a$ concentrations $\left(45.3 \mathrm{mg} \mathrm{m}^{-2}\right)$ at station (NP6) over the Prince Edward Island (PEI) shelf were the highest of all the productivity stations. Micro-phytoplankton dominated the community (61.4\%) to attain the highest integrated biomass recorded $\left(45.3 \mathrm{mg} \mathrm{m}^{-2}\right)$ for this size fraction, followed by pico- and nano-phytoplankton in relative abundance (Fig. 7f). Total $\int \rho \mathrm{N}$ for this station (NP6) was high (Fig. 8f), second only to the AF (NP3) and dominated by $\rho \mathrm{NH}_{4}(64 \%)$. Although no Fe measurements were made during this study, it is not unreasonable to suppose that the downstream regions of the Prince Edward Islands are also Fe-enriched, particularly during winter and in early spring (September, October). Station NP6 is situated $\sim 16 \mathrm{~km}$ north of Prince Edward Islands, which despite being in relatively deep shelf waters $(\sim 1700 \mathrm{~m})$ is situated downstream of the meandering SAF, which is steered past and north of the Islands by bottom topography (Ansorge et al., 1999). As such, it is likely that $\mathrm{Fe}$ is injected into the region. A similar scenario is observed at the Crozet Islands, where downstream increases in $\mathrm{Fe}$ from both benthic sediments and from island run-off result in elevated $\rho \mathrm{NO}_{3}$ and f-ratios north of the islands (Lucas et al., 2007; Pollard et al., 2009). The upward flux of dissolved $\mathrm{Fe}$ from shallow shelf sediments could encourage $\rho \mathrm{NO}_{3}$ at depth, provided that light is not limiting and potentially account for the increasing f-ratios with depth (Table 1) and the higher $\rho * \mathrm{~N}$ values relative to NP4 and NP5 (Fig. 10). Although this station had the highest integrated fratio of all productivity stations (Fig. 9), it is still very low (0.14). Around Crozet, the impact of Fe-enrichment on phytoplankton $\mathrm{N}$ metabolism waned significantly by early to mid summer (November to December) as surface Fe pools were depleted, resulting in a decline in the average f-ratio from $\sim 0.45$ to $<0.2$ (Lucas et al., 2007). A similar seasonal trend would also be expected at the Prince Edward Islands. Given that this study was undertaken in April/May, in late summer, it is therefore not surprising that an $\mathrm{Fe}$ mediated response in the f-ratio was barely observed.

Micro-phytoplankton dominated communities such as those observed at NP6 are thus likely to be alleviated from 
Fe stress, particularly in spring, and significant in terms of POC export. Furthermore, regionally elevated new production rates no doubt support the avifaunal and benthic community food webs, as well as creating a local and seasonal $\mathrm{CO}_{2}$ "sink", as is observed at the Crozet islands (Bakker et al., 2007).

\section{Conclusions}

Our north-south transect from subtropical to subantarctic waters revealed two regions of contrasting characteristics. The most conspicuous changes in chemical, physical and biological variables occurred at the STF, which separated the two regions. To the north, a warm, salty, highly stratified water column with low nitrate concentrations distinguished an eastern region of the subtropical SW Indian, while the region south of the STF was characterised by cold nutrient-rich Subantarctic Surface Waters of the Southern Ocean.

Subtropical waters were characterised by low concentrations of small phytoplankton cells and very low f-ratios, indicating productivity based almost entirely on recycled ammonium and urea. Micro-phytoplankton growth was probably limited by the strong seasonal thermocline, which creates sufficient vertical stratification to prevent the upward flux of nutrients into the euphotic zone. The biomass of small cells was most likely controlled by micro-zooplankton grazing, which was responsible for conserving reduced $\mathrm{N}$ pools. While respiratory $\mathrm{CO}_{2}$ losses are probably high, $\mathrm{POC}$ export and biological $\mathrm{CO}_{2}$ draw down is expected to be minimal.

Crossing the STF into subantarctic surface waters, total chl- $a$ concentrations increased and micro-phytoplankton became more prominent, although nano- and picophytoplankton still typically dominated. South of the STF, nutrient flux into surface waters was likely maintained by turbulent mixing and large-scale upwelling. However, despite the predominance of $\mathrm{NO}_{3}, \rho \mathrm{N}$ in this region was still based primarily on regenerated $\mathrm{N}$ in the form of $\mathrm{NH}_{4}$ and urea; where Si limitation, light-limited deep mixing and likely $\mathrm{Fe}$ deficiency curtailed significant new production by microphytoplankton. The role of macro-zooplankton grazing also cannot be ignored as a controlling mechanism. Very low fratios mean that $\mathrm{CO}_{2}$ draw down is likely to be lower than expected from the large $\mathrm{NO}_{3}$ pool in this area.

Increased concentrations of micro-phytoplankton and rates of new production did however occur at oceanic frontal regions, and in the vicinity of the Prince Edward Islands; in the latter case most likely due to local Fe-enrichment as observed at the nearby Crozet Islands. Regions such as these provide important areas for local but significant POC export and biological $\mathrm{CO}_{2}$ draw-down in an overall HNLC Southern Ocean.
Acknowledgements. Special thanks go to the Plymouth Marine Laboratory and in particular to Andy Rees for his indispensable practical help in running the mass spectrometer. We would like to thank the DEAT and Southern Ocean Group at Rhodes University for their contribution to the practical part of this study. Thank you also to the officers and crew of the M/V SA Agulhas for your courteous support throughout the cruise. We would like to thank our reviewers for their valuable contributions to our manuscript and in particular to our anonymous reviewer number 1 for their detailed and insightful comments which were beneficial to the improvement of this manuscript for publication.

Edited by: M. Hoppema

\section{References}

Allanson, B. R., Hart, R. C., and Lutjerharms, J. R. E.: Observations on the nutrients, chlorophyll and primary production of the Southern Ocean south of Africa, South African Journal of Antarctic Research, 10(11), 3-14, 1981.

Ansorge, I. J., Froneman, P. W., Pakhamov, E. A., Lutjerharms, J. R. E., Perissinotto, R., and van Ballegooyen, R. C.: Physicalbiological coupling in the waters surrounding the Prince Edward Islands (Southern Ocean), Polar Biol., 21, 135-145, 1999.

Atkinson, A., Whitehouse, M. J., Priddle, J., Cripps, G. C., Ward, P., and Brandon, M. A.: South Georgia, Antarctica: a productive, cold water, pelagic ecosystem, Mar. Ecol. Prog.-Ser., 216, 279308, 2001.

Bakker, D. C. E., Nielsdottir, M. C., Morris, P., Venables, H. J., and Watson, A. J.: The island mass effect and biological carbon uptake for the subantarctic Crozet Archipelago, Deep-Sea Res. II, 54, 2174-2190, 2007.

Barange, M., Pakhomov, E. A., Perissinotto, R., Froneman, P. W., Verheye, H. M., Taunton-Clark, J., and Lucas, M. I.: Pelagic community structure of the subtropical Convergence region south of Africa and in the mid-Atlantic Ocean, Deep-Sea Res., 45, 1663-1687, 1998.

Barrie, A., Davies, J. E., Park, A. J., and Workman, C. T.: Continuous-flows stable isotope analysis for biologists, Spectroscopy, 4, 42-52, 1989.

Bathmann, U., Priddle, J., Treguer, P., Lucas, M. I., Parslow, J., and Hall, J.: Plankton ecology and biogeochemistry in the Southern Ocean: A first review of Southern Ocean JGOFS, in: The Changing Ocean carbon Cycle: a midterm synthesis of the Joint Global Ocean Flux Study, edited by: Hanson, R. B., Ducklow, H. W., and Field, J. G., IGBP Book Series 5, Cambridge University Press, London, 2000.

Belkin, I. M. and Gordon, A.L.: Southern Ocean fronts from the Greenwich meridian to Tasmania, J. Geophys. Res., 101, 36753696, 1996.

Blain, S., Treguer, P., Belviso, S., Bucciarelli, E., Denis, M., Desabre, S., Fial, M., Jézéquel, V. M., Le Fèvre, J., Mayzaud, P., Marty, J., and Razouls, S.: A biogeochemical study of the island mass effect in the context of the iron hypothesis: Kerguelen Islands, Southern Ocean, Deep-Sea Res. II, 48(1), 163-187, 2001.

Blain, S., Queguiner, B., Armand, L., Belviso, S., Bombled, B., Bopp, L., Bowie, A., Brunet, C., Brussaard, C., Carlotti, F., 
Christaki, U., Corbiere, A., Durand, I., Ebersbach, F., Fuda, J., Garcia, N., Gerringa, L., Griffiths, B., Guigue, C., Guillerm, C., Jacquet, S., Jeandel, C., Laan, P., Lefevre,., D., Lo Monaco, C., Malits, A., Mosseri, J., Obernosterer, I., Park, Y., Picheral, M., Pondaven, P., Remenyi, T., Sandroni, V., Sarthou, G., Savoye, N., Scouarnec, L., Souhaut, M., Thuiller, D., Timmermans, K., Trull, T., Uitz, J., van Beek, P., Veldhuis, M., Vincent, D., Viollier, E., Vong, L., and Wagener, T.: Effect of natural iron fertilization on carbon sequestration in the Southern Ocean, Nature, 446, 10701074, 2007.

Boyd, P., Watson, A., Law, C., Abraham, E., Trull, T., Murdoch, R., Bakker, D., Bowie, A., Buesseler, K. O., Chang, H., Charette, M., Croot, P., Downing, K., Frew, R., Gall, M., Hadfield, M., Hall, J., Harvey, M., Jameson, G., LaRoche, J., Liddicoat, M., Ling, R., Maldonado, M., McKay, R. M., Nodder, S., Pickmere, S., Pridmore, R., Rintoul, S., Safi, K., Sutton, P., Strzepek, R., Tanneberger, K., Turner, S., Waite, A., and Zeldis, J.: A mesoscale phytoplankton bloom in the polar Southern Ocean stimulated by iron fertilization, Nature, 407, 695-702, 2000.

Boyd, P. W., Jickells, T., Law, C. S., Blain, S., Boyle, E. A., Buesseler, K. O., Coale, K. H., Cullen, J. J., de Baar, H. J. W., Follows, M., Harvey, M., Lancelot, C., Levasseur, M., Owens, N. P. J., Pollard, R., Rivkin, R. B., Sarmiento, J., Schoemann, V., Smetacek, V., Takeda, S., Tsuda, A., Turner, S., and Watson, A. J.: Mesoscale Iron enrichment experiments 1993-2005: Synthesis and future directions, Science, 315, 612-617, 2007.

Bury, S. J., Owens, N. J. P., and Preston, T.: ${ }^{13} \mathrm{C}$ and ${ }^{15} \mathrm{~N}$ uptake by phytoplankton in the marginal ice zone of the Bellingshausen Sea, Deep-Sea Res. II, 42, 1225-1252, 1995.

Coale, K. H., Johnson, K. S., Chavez, F. P., Buesseler, K. O., Barber, R. T., Brzezinski, M. A., Cochlan, W. P., Falkowski, P. G., Bauer, J. E., Wanninkhof, R. H., Kudela, R. M., Altabet, M. A., Hales, B. E., Takahashi, T., Landry, M. R., Bidigare, R. R., Wang, X., Chase, Z., Strutton, P. G., Friederich, G. E., Gorbunov, M. Y., Lance, V. P., Hilting, A. K., Hiscock, M. R., Demarest, M., Hiscock, W. T., Sullivan, K. F., Tanner, S. J., Gordon, R. M., Hunter, C. N., Elrod, V. A., Fitzwater, S. E., Jones, J. L., Tozzi, S., Koblizek, M., Roberts, A. E., Brewster, J., Ladizinsky, N., Smith, G., Cooper, D., Timothy, D., Brown, S. L., Selph, K. E., Sheridan, C. C., Twining, B. S., and Johnson, Z. I.: Southern Ocean iron enrichment experiment: carbon cycling in the highand low-Si waters, Science, 304, 408-414, 2004.

Cochlan, W. P.: Nitrogen uptake in the Southern Ocean, in: Nitrogen in the Marine Environment, 2nd Edn., edited by: Capone, D. G., Bronk, D. A., Mulholland, M. R., and Carpenter, E. J., Academic Press, Elsevier, 569-596, 2008.

Cullen, J. J.: Hypotheses to explain high-nutrient conditions in the open sea, Limnol. Oceanogr., 36, 1578-1599, 1991.

De Baar, H. J. W., Buma, A. G. J., Nolting, R. F., Cadee, G. C., Jacques, G., and Treguer, P. J.: On iron limitation in the Southern Ocean: Experimental observations in the Weddel and Scotia Seas, Mar. Ecol. Prog.-Ser., 65, 105-122, 1990.

De Baar, H. J. W., Boyd, P. W., Coale, K. H., Landry, M. R., Tsuda, A., Assmy, P., Bakker, D. C. E., Bozec, Y., Barber, R. T., Brzezinski, M. A., Buesseler, K. O., Boye, M., Croot, P. L., Gervais, F., Gorbunov, M. Y., Harrison, P. J., Hiscock, W. T., Laan, P., Lancelot, C., Law, C. S., Levasseur, M., Marchetti, A., Millero, F. J., Nishioka, J., Nojiri, Y., Van Oijen, T., Riebesell, U., Rijkenberg, M. J. A., Saito, H., Takeda, S., Timmermans, K.
R., Veldhuis, M. J. W., Waite, A. M., Wong, C. S. M., Bugg, W., Efremenko, Y., Kamyshkov, Y., Kozlov, A., Nakamura, Y., Karwowski, H. J., Markoff, D. M., Nakamura, K., Rohm, R. M., Tornow, W., Wendell, R., Chen, M. J., Wang, Y. F., Piquemal, F., and Wong, C. S. D. M.: Synthesis of iron fertilization experiments: From the Iron Age in the Age of Enlightenment, J. Geophys. Res., 110, C09S16, doi:10.1029/2004JC002601, 2005.

Diaz, F. and Raimbault, P.: Nitrogen regeneration and dissolved organic nitrogen release during spring in a NW Mediterranean coastal zone (Gulf of Lions): implications for the estimation of new production, Mar. Ecol. Prog.-Ser., 197, 51-65, 2000.

Donald, K. M., Joint, I., Rees, A. P., Woodward, E. M. S., and Savidge, G.: Uptake of carbon, nitrogen and phosphorus by phytoplankton along the $20^{\circ} \mathrm{W}$ meridian in the NE Atlantic between $57.5^{\circ} \mathrm{N}$ and $37^{\circ} \mathrm{N}$, Deep-Sea Res. II, 48, 873-897, 2001.

Dore, J. E. and Karl, D. M.: Nitrification in the euphotic zone as a source for nitrite, nitrate, and nitrous oxide at station ALOHA, Limnol. Oceanogr., 41, 1619-1628, 1996.

Dower, K. M. and Lucas, M. I.: Photosynthesis-irradiance relationships and production associated with a warm-core ring shed from the Subtropical Retroflection south of Africa, Mar. Ecol. Prog.Ser., 95, 141-154, 1993.

Dugdale, R. C. and Goering, J. J.: Uptake of new and regenerated forms of nitrogen in primary productivity, Limnol. Oceanogr., 12(2), 196-206, 1967.

Dugdale, R. C. and Wilkerson, F. P.: Silicate regulation of new production in the equatorial Pacific upwelling, Nature, 391, 270273, 1998.

Eppley, R., Rogers, J., and McCarthy, J.: Half-Saturation Constants for Uptake of Nitrate and Ammonium by Marine Phytoplankton, Limnol. Oceanogr., 14, 912-920, 1969.

Eppley, R. W.: New Production: History, Methods and Problems, in: Productivity of the Ocean: Present and Past, edited by: Berger, W. H., Smetacek, V. S., and Wefer, G., John Wiley and Sons, New York, 85-97, 1989.

Eppley, R. W. and Peterson, B. J.: Particulate organic matter flux and planktonic new production in the deep ocean, Nature, 282, 677-680, 1979.

Falkowski, P. G. and Raven, J. A.: Aquatic photosynthesis, Blackwell Science, Oxford, 1997.

Falkowski, P. G., Scholes, R. J., Boyle, E., Canadell, J., Canfield, D., Elser, J., Gruber, N., Hibbard, K., Hogberg, P., Linder, S., Mackenzie, F. T., Moore III, B., Pedersen, T., Rosenthal, Y., Seitzinger, S., Smetacek, V., and Steffen, W.: The global carbon cycle: A test of our knowledge of earth as a system, Science, 290, 291-296, 2000.

Fernandez, C. and Raimbault, P.: Nitrogen regeneration in the Northeast Atlantic Ocean and its impact on seasonal new, regenerated and export production, Mar. Ecol. Prog.-Ser., 337, 79-92, 2007.

Froneman, P. W. and Perissinotto, R.: Microzooplankton grazing and protozooplankton community structure in the South Atlantic and in the Atlantic sector of the Southern Ocean, Deep-Sea Res. I, 43, 703-721, 1996.

Geider, R. J. and La Roche, J.: Redfield revisited: variability of $\mathrm{C}: \mathrm{N}: \mathrm{P}$ in marine microalgae and its biochemical basis, Eur. J. Phycol., 37, 1-17, 2002.

Gervais, F., Riebesell, U., and Gorbunov, M. Y.: Changes in primary productivity and chlorophyll a in response to iron fertilization in 
the Southern Polar Frontal Zone, Limnol. Oceanogr., 47, 13241335, 2002.

Glibert, P. M., Lipschultz, F., McCarthy, J. J., and Altabet, M. A.: Isotope dilution models of uptake and remineralization of ammonium by marine plankton, Limnol. Oceanogr., 27, 639-650, 1982.

Glibert, P. M., Miller, C. A., Garside, C., Roman, M. R., and McManus, G. B.: $\mathrm{NH}_{4}^{+}$regeneration and grazing: interdependent processes in size-fractionated ${ }^{15} \mathrm{NH}_{4}^{+}$experiments, Mar. Ecol.Prog. Ser., 82, 65-74, 1992.

Grasshoff, K. M., Ehrhardt, M., and Kremling, K.: Determination of urea (9.5), in: Methods of seawater analysis, 2nd Edn., Verlag Chemie, Wienheim, Germany, 158-162, 1983.

Grundlingh, M. L.: Observation of a large meander in the Agulhas Current, J. Geophys. Res., 84, 3776-3778, 1979.

Harrison, W. G. and Harris, I. R.: Isotope dilution and its effects on measurements of nitrogen and phosphorous uptake by oceanic microplankton, Mar. Ecol.-Prog. Ser., 27, 253-261, 1986.

Hoffmann, L. J., Peeken, I., Lochte, K., Assmy, P., and Veldhuis, M.: Different reactions of Southern Ocean phytoplankton size classes to iron fertilization, Limnol. Oceanogr., 51(3), 12171229, 2006.

Honjo, S., Francois, R., Manganini, S., Dymond, J., and Collier, R.: Particle fluxes to the interior of the Southern Ocean in the Western Pacific sector along $170^{\circ}$ W, Deep-Sea Res. II, 47(1516), 3521-3548, 2000.

Kirk, J. T. O.: Light and photosynthesis in aquatic ecosystems, 2nd Edn., Cambridge University Press, Cambridge, 1994.

Knauer, G. A., Redalje, D. G., Harrison, W. G., and Karl, D. M.: New production at the VERTEX time-series site, Deep-Sea Res., 37(7), 1121-1134, 1990.

Laubscher, R. K., Perissinotto, R., and McQuaid, C. D.: Phytoplankton production and biomass at frontal zones in the Atlantic sector of the Southern Ocean, Polar Biol., 13, 471-481,1993.

Longhurst, A. R.: Role of the marine biosphere in the global carbon cycle, Limnol. Oceanogr., 36, 1507-1526, 1991.

Lucas, M. I., Seeyave, S., Sanders, R., Moore, M., and Williamson, R.: New and regenerated production during the Crozex study, Deep-Sea Res. II, 54, 2138-2173, 2007.

Lutjeharms, J. R. E.: Location of frontal systems between Africa and Antarctica; some preliminary results, Deep-Sea Res., 32, 1499-1509, 1985.

Lutjeharms, J. R. E. and Ansorge, I. J.: The Agulhas Return Current, J. Marine Syst., 30(1-2), 115-138, 2001.

Lutjeharms, J. R. E. and Valentine, H. R.: Southern Ocean thermal fronts south of Africa, Deep-Sea Res., 31, 1461-1475, 1984.

Lutjeharms, J. R. E., Fromme, G. A. W., and Valentine, H. R.: Oceanic frontal systems between Africa and Antarctica, EOS, Eos. T. Am. Geophys. Un., 62, p. 942, 1981.

Lutjeharms, J. R. E., Walters, N. M., and Allanson, B. R.: Oceanic frontal systems and biological enhancement, in: Antarctic nutrient cycles and food webs, edited by: Siegfried, W. R., Condy, P. R., and Laws, R. M., Springer-Verlag, Berlin, 11-21, 1985.

Martin, J. H. and Fitzwater, S.: Iron deficiency limits phytoplankton growth in the north-east Pacific subarctic, Nature, 331, 341-343, 1988.

Martin, J. H., Gordan, R., Fitzwater, S., and Brokenkow, W.: VERTEX: phytoplankton/iron studies in the Gulf of Alaska, DeepSea Res., 36, 649-680, 1989.
Martin, J. H., Gordon, R. M., and Fitzwater, S. E.: The case for iron, Limnol. Oceanogr., 36, 1793-1802, 1991.

Metzl, N., Tilbrook, B., and Poison, A.: The annual $f \mathrm{CO}_{2}$ cycle and the air-sea $\mathrm{CO}_{2}$ flux in the sub-Antarctic Ocean, Tellus, 51B, 849-861, 1999.

Moore, C. M., Mills, M. M., Milne, A., Langlois, R., Achterberg, E. P., Lochte, K., Geider, R. J., and La Roche, J.: Iron limits primary productivity during spring bloom development in the central North Atlantic, Glob. Change Biol., 12, 626-634, 2006.

Moore, M. C., Seeyave, S., Hickman, A. E., Allen, J. T., Lucas, M. I., Planquette, H., Pollard, R., and Poulton, A. J.: Iron-light interactions during the CROZet natural iron bloom and EXport experiment (CROZEX) I: phytoplankton growth and photophysiology, Deep-Sea Res. II, 54, 2045-2065, 2007a.

Moore, M. C., Hickman, A. E., Poulton, A. J., Seeyave, S., and Lucas, M. I.: Iron-light interactions during the CROZet natural iron bloom and Export experiment (CROZEX) II: taxonomic responses and elemental stoichiometry, Deep-Sea Res. II, 54, 2066-2084, 2007b.

Morel, A.: Light and marine photosynthesis: A spectral model with geochemical and climatological implications, Prog. Oceanogr., 26, 263-306, 1991.

Nelson, D. M. and Smith, W. O.: Sverdrup re-visited: critical depths, maximum chlorophyll levels, and the control of Southern Ocean productivity by the irradiance-mixing regime, Limnol. Oceanogr., 36, 1650-1661, 1991.

Orsi, A. H., Whitworth, T., and Nowlin, W. D.: On the meridional extent and fronts of the Antarctic Circumpolar Current, DeepSea Res., 42, 641-673, 1995.

Owens, N. J. P. and Rees, A. P.: Determination of nitrogen-15 at submicrogram levels of nitrogen using automated continuousflow isotope ratio mass spectrometry, Analyst, 114, 1655-1657, 1989.

Pakhomov, E. A., Froneman, P. W., and Ansorge, I. J.: Prince Edward Islands' offshore oceanographic study: report of research cruise April-May 1997, S. Afr. J. Sci., 94, 153-156, 1998.

Pakhomov, E. A., Ansorge, I. J., McQuaid, C. D., Kohrs, S., Waldron, H., Hunt, B., Gurney, L., Kaehler, S., Lawrie, S., Held, C., and Machu, E.: The fourth cruise of the Marion Island Oceanographic Survey (MIOS-IV), April to May 1999, S. Afr. J. Sci., 95, 1-3, 1999.

Park, Y. H., Gamberoru, L., and Charriaud, E.: Frontal structure, water masses and circulation in the google scholarCrozet Basin, J. Geophys. Res., 98, 2361-12385, 1993.

Parsons, T. R., Maita, Y., and Lalli, C. M.: A manual of chemical and biological methods for seawater analysis, Pergamon Press, Oxford, 173 pp., 1984.

Plancke, J.: Phytoplankton biomass and productivity in the Subtropical Convergence area and the shelves of the western Indian subantarctic islands, in: Adaptions within Antarctic ecosystems, edited by: Liano, G. A., Smithsonian Institution, Washington, D.C., 51-73, 1977.

Planquette, H., Statham, P. J., Fones, G. R., Charette, M. A., Moore, M., Salter, I., Nédélec, H., Taylor, S. L., French, M., Baker, A. R., Mahowald, N., and Jickells, T. D.: Dissolved iron in the vicinity of the Crozet Islands, Southern Ocean, Deep-Sea Res. II, 54, 1999-2019, 2007.

Pollard, R. T. and Read, J. F.: Circulation pathways and transports of the Southern Ocean in the vicinity of the Southwest Indian 
Ridge, J. Geophys. Res., 106, 2881-2898, 2001.

Pollard, R. T. and Regier, L. A.: Vorticity and vertical circulation at an ocean front, J. Phys. Oceanogr., 22, 609-625, 1992.

Pollard, R. T., Lucas, M. I., and Read, J. F.: Physical controls on biogeochemical zonation in the Southern Ocean, Deep-Sea Res. II, 49, 16, 3289-3305, 2002.

Pollard, R., Sanders, R., Lucas, M., and Statham, P.: The Crozet natural iron bloom and export experiment (CROZEX), Deep-Sea Res. II, 54, 1905-1914, 2007.

Pollard, R. T., Salter, I., Sanders, R. J., Lucas, M. I., Moore, C. M., Mills, R. A., Statham, P. J., Allen, J. T., Baker, A. R., Bakker, D. C. E., Charette, M. A., Fielding, S., Fones, G. R., French, M., Hickman, A. E., Holland, R. J., Hughes, J. A., Jickells, T. D., Lampitt, R. S., Morris, P. J., Nedelec, F. H., Nielsdottir, M., Planquette, H., Popova, E. E., Poulton, A. J., Read, J. F., Seeyave, S., Smith, T., Stinchcombe, M., Taylor, S., Thomalla, S. J., Venables, H. J., Williamson, R., and Zubkov, M. V.: Southern Ocean deep-water carbon export enhanced by natural iron fertilization, Nature, 457, 577-580, 2009.

Probyn, T. A., Waldron, H. N., Searson, S., and Owens, N. J. P.: Diel variability in nitrogenous nutrient uptake at photic and subphotic depths, J. Plankton. Res., 18, 2063-2079, 1996.

Raimbault, P., Slawyk, G., Boudjellal, B., Coatanoan, C., Conan, P., Coste, B., Garcia, N., Moutin, T., and Pujo-Pay, M.: Carbon and nitrogen uptake and export in the Equatorial Pacific at $150^{\circ} \mathrm{W}$ : Evidence of an efficient regenerated production cycle, J. Geophys. Res., 104, 3341-3356, 1999.

Raven, J. A.: Physiological consequences of extremely small size for autotrophic organisms in the sea, Can. Bull. Fish. Aquat. Sci., 214, 1-70, 1986.

Read, J. F. and Pollard, R. T.: Structure and transport of the Antarctic Circumpolar Current and Agulhas Return Current at $40^{\circ} \mathrm{E}, \mathrm{J}$. Geophys. Res., 98, 12281-12295, 1993.

Read, J. F., Lucas, M. I., Pollard, R. T., and Holley, S. E.: Phytoplankton, nutrients and hydrography in the frontal zone between the Southwest Indian Subtropical gyre and the Southern Ocean, Deep-Sea Res. I, 47, 2341-2368, 2000.

Rees, A. P., Malcolm, E., Woodward, S., Robinson, C., Cummings, D. G., Tarran, G. A., and Joint, I.: Size-fractionated nitrogen uptake and carbon fixation during a developing coccolithophore bloom in the North Sea during June 1999, Deep-Sea Res. Part II, 49(15), 2905-2927, 2002.

Salter, I., Lampitt, R. S., Sanders, R. Poulton, A. J., Boorman, B., and Saw, K.: Estimating Export Production From CROZEX using PELAGRA: a Novel Drifting sediment trap, Deep-Sea Res. II, 54, 2233-2259, 2007.

Sanders, R., Morris, P. J., Poulton, A. J., Stinchcombe, M. C., Charalampopoulou, A., Lucas, M. I., and Thomalla,S. J.: Does a ballast effect occur in the surface ocean?, Geophys. Res. Lett., 37, L08602, doi:10.1029/2010GL042574, 2010.
Schlitzer, R.: Electronic Atlas of WOCE Hydrographic and Tracer Data Now Available, Eos Trans. AGU, 81(5), p. 45, 2000.

Schlitzer, R.: Ocean Data View, http://www.awi-bremerhaven.de/ GEO/ODV (last access: 13 May 2010), 2002.

Smetacek, V.: Diatoms and the Silicate factor, Nature, 391, 224225, 1998.

Thomalla, S. J., Poulton, A. J., Sanders, R., Turnewitsch, Holligan, P. M., and Lucas, M. I.: Variable export fluxes and efficiencies for calcite, opal and organic carbon in the Atlantic Ocean: A ballast effect in action?, Global Biogechem. Cy., 22, GB1010, doi:10.1029/2007GB002982, 2008.

Timmermans, K. R., van der Wagt, B., and de Baar, H. J. W.: Growth rates, half-saturation constants, and silicate, nitrate, and phosphate depletion in relation to iron availability of four large, open-ocean diatoms from the Southern Ocean, Limnol. Oceanogr., 49(6), 2141-2151, 2004.

Tremblay, J. E., Klein, B., and Legendre, L.: Estimation of fratios in oceans based on phytoplankton size structure, Limnol Oceanogr., 42, 595-601, 1997.

Tremblay, J. E., Legendre, L., Klein, B., and Therriault, J. C.: Sizedifferential uptake of nitrogen and carbon in a marginal sea (Gulf of St. Lawrence, Canada): significance of diel periodicity and urea uptake, Deep-Sea Res. II, 47, 489-518, 2000.

Varela, M. M., Bode, A., Fernández, E., Gónzalez, N., Kitidis, V., Varela, M., and Woodward, E. M. S., Nitrogen uptake and dissolved organic nitrogen release in planktonic communities characterised by phytoplankton size-structure in the Central Atlantic Ocean, Deep Sea Res. I, 52(9), 1637-1661, 2005.

Volk, T. and Hoffert, M. I.: Ocean carbon pumps: analysis of relative strengths and efficiencies in ocean-driven atmospheric $\mathrm{CO}_{2}$ changes, in: The carbon cycle and atmospheric $\mathrm{CO}_{2}$ : natural variations Archean to Present, edited by: Sundguist, E. T. and Broeker, W. S., American Geophysical Union, Washington DC, 627 pp., 1985.

Waldron, H. N., Attwood, C. G., Probyn, T. A., and Lucas, M. I.: Nitrogen dynamics in the Bellingghausen Sea during the austral spring of 1992, Deep-Sea Res. II, 42, 1253-1276, 1995.

Weeks, S. J. and Shillington, F. A.: Interannual scales of variation of chlorophyll concentrations from CZCS data in the Benguela Upwelling System and the Subtropical Convergence south of Africa, J. Geophys. Res., 99, 7385-7399, 1994.

Whitworth, T. and Nowlin, W. D.: Water masses and currents of the Southern Ocean at the Greenwich Meridian, J. Geophys. Res., 92, 6462-6476, 1987.

Yool, A., Martin, A. P., Fernandez, C., and Clark, R. J.: Not so new: the significance of nitrification for oceanic "new" production, Nature 447, 999-1002, 2007. 